\title{
THE EXTRATERRITORIAL EFFECT OF PROBATE DECREES *
}

\author{
BY BERT E. HOPKINS $t$
}

WITH improvement in means of travel and communication and with a more fluid population, conflict of laws problems tend to increase in number and importance and to call for effective solution. The numerous conflict of laws problems incident to our federated form of government are met and solved in a variety of ways. In the course of political and legal development many important matters which in an earlier era vere subject to varying state laws have been brought within the control of federal law. Legal problems remaining subject to state control frequently are met through wide adoption of uniform legislation which eliminates many substantive law conflicts among the states. Where such legislation is not adopted, the problems are met through common law or statutory conflict of laws rules in the several states. In a few instances proposed uniform statutory conflict of laws rules have been promulgated. In certain areas of private law today there are conflict of laws problems still awaiting effective solution despite the existence of common law conflict of laws rules and some state legislation.

Administration of decedents' estates is a case in point. Where a decedent leaves property in several states, the situation demands an efficient, unified administration without regard to state lines. It seems improbable that federal law will provide such a system of administration in the foreseeable future, and it is not readily apparent that Congress would have constitutional power to establish a system of federal administration for estates extending across state lines. Present uniform acts are fragmentary and have not been widely adopted. ${ }^{1}$ Other existing legislation

* This article is a portion of a larger study of decedents' estates in conflict of laws submitted in partial fulfillment of the requirements of the Faculty of Law, Columbia University, for the degree of Doctor of Science of Law. See Conflict of Lames in Administration of Decedents' Intangibles (1943) 28 Iowa L. Rev. 422, 613. The writer is indebted for helpful suggestion and criticism to several members of the Faculty of Law, Columbia University, and especially to Professor Elliott Cheatham. The authur also has had the benefit of a perusal of this paper by Professor Thomas E. Attinson of the University of Missouri School of Law, draftsman for the Special Committee on Uniform Ancillary Administration of Estates Act, National Conference of Commissioners on Uniform State Laws.

$\div$ Professor of Law, University of Idaho.

1. Uniforns Wills Act, Foretgn Probated, 9 U. L. A. (1942) 755, adopted in five states; UNIForar WILLS ACT, Foreigar ExecuTED, adopted in thirteen states, superseded since 1940 by section 7 of the Modec Execution of WiLs ACr, 9 U. L. A. (1942) 277, adopted in one state. The Commissioners on Uniform State Laws now have under conlsideration tentative drafts of two additional acts relating to powers of forcign personal representatives and ancillary administration of estates. See Hasproor of THE NATtosial Conference of Coararissioners on Uniforar State Laws (1942) 237 et seq. 
is usually likewise incomplete. Common law rules thus far developed are uncertain and conflicting and usually do not meet the needs of a unified administration. It is proposed in this essay to explore but one of the conflict of laws problems in the administration of decedents' estates, namely, the extraterritorial effect of probate decrees. The essential question is whether a single contest or opportunity to contest a will in the United States is sufficient and conclusive, or whether a contest may be had in more than one state. The related question of whether a judgment which is foreign in the international sense should be recognized as conclusive in this country presents distinctive elements of both law and policy, and will not be considered here.

The problem here to be considered may be generalized and stated in familiar symbolic conflict of laws terms. The property of a decedent is situated at the time of his death in more than one state. A probate proceeding is had in one state, F-1, which results in an adjudication either of testacy or of intestacy. Thereafter, a judicial proceeding takes place in a second state, F-2, concerning the local property of the same decedent, and in the second proceeding reliance is placed by one of the parties upon the F-1 judgment. What recognition or effect will be accorded to the F-1 judgment in the second forum?

Effective analysis of the problem thus broadly generalized requires that it be broken down in terms of factors considered important by the courts. It becomes important, for example, to know the state in which the decedent was domiciled at the time of death; whether the property involved in F-2 is real or personal property; whether the parties to the proceeding in F-2 were before the court in the F-1 litigation; and what the legislature in the state of $\mathrm{F}-2$ has provided, not only as to the specific effect of foreign probate decrees, but also as to local recording or probate of foreign executed wills. Even when this breakdown has been made, the reported decisions reveal a wide variety of conflicting results supported by equally conflicting legal theories. The present objective is not primarily to vindicate or to reject any or all of those theories, but to reexamine the results obtained through their application. The general criterion which has been adopted is convenience and expediency in getting the job of probate administration done with a minimum of confusion and expense after every person interested in the estate has had an opportunity to be heard in an appropriate forum. It may be hoped the effort will be helpful to draftsmen in the field where legislation is needed. ${ }^{2}$

2. Improvements in probate practice are under consideration in a number of states, and the American Bar Association Committee on Probate Jurisdiction and Practice has concerned itself with the drafting of a model probate code. ProceEdings, AdDresses AND Reports, Section of Real Property, Probate and Trust Law, American bar AssoCIATION (1940) 85-87. Other than summary treatment in the textbooks on wills and conflict of laws, very little discussion of the present subject has appeared in print. More 


\section{Preltminary Constderation of "Jurisdiction"}

Many of the judicial opinions on the extraterritorial effect of probate decrees, as will more fully appear, proceed in terms of "jurisdiction" of the foreign court and of "jurisdiction" of the court in which recognition of the foreign decree is sought. There is grave danger of confusion in use of a term which, like the word "jurisdiction," is capable of carrying any one of several distinct meanings. Need for some preliminary clarification is indicated.

In McDonald v. Mabee, Mr. Justice Holmes observed that "The foundation of jurisdiction is physical power. ..."3 But in another opinion, while recognizing that jurisdiction is founded upon power and that a sovereign state theoretically could draw a line of fire around its boundaries and recognize nothing that happened outside, the same justice added significantly, "But it prefers to consider itself civilized and to act accordingly." 4 Conflict of laws rules are an important part of the civilized equipment with which a court attempts properly to evaluate the foreign elements or contacts which are found in a judicial dispute. Those rules, if prudently formulated, may contribute mightily to efficient handling of litigation, especially under our federated form of government where the facts of a great number of cases present a multiple-state aspect. Sometimes the problem is whether there are enough local elements, or the traditionally proper local elements as compared with the foreign elements in the cause of action, to warrant the local court hearing the matter at all; this is a problem of "jurisdiction" in one of the commonly accepted meanings of that term. Sometimes the problem is whether the court in deciding the case should forsake its own substantive law rules in favor of different substantive law rules prevailing in another state with which the cause of action has important contacts; this is the problem of "choice of law." Again, the foreign element in the case may be the fact that a foreign court has already passed upon the same dispute, or some aspect of it, and the second forum is confronted with the problem of "effect of a foreign judgment."

We are concerned here essentially with the third of these general conflict of laws problems and only incidentally with the other two. In most cases where a court has determined the effect to be given to a foreign probate

than a decade ago Professor Carey treated the matter in a helpful article, A Suggestcd Fundanental Basis of Jurisdiction with Special Emphasis on Judicial Procecdings Affecting Decedents' Estates (1929) 24 ILL. L. REv. 44, 170.

A draftsman of reform legislation might well consider the selated problem, nut treated herein, of what effect should be given to a judgment of a sister state establishing construction of a will. See 4 PaGE, Wris (3d ed. 1941) §1606.

3. 243 U. S. 90,91 (1917).

4. Direction Der Disconto-Gesellschaft v. United States Steel Corp., 267 U. S. 22, 28 (1925). 
decree it has not been troubled at all with its own "jurisdiction" or that of the foreign court in the sense in which that word is used above. Typically there is property of the estate in each of the states involved, and the presence of property within the state is universally recognized as a factor warranting a local probate proceeding. Nor is the court troubled in the typical case with the validity of the foreign decree in the state where it was rendered, which is another and perhaps the basic meaning of "jurisdiction." If such invalidity exists, due to any one of a wide variety of possible procedural errors, including failure to make proper service of process, there is indeed an independent and sufficient reason for disregarding the judgment in the local proceeding, on the ground that the foreign court lacked "jurisdiction." But granting that the foreign court was competent under its own laws and procedure to enter the judgment in question, there remains the problem of its extraterritorial effect. This problem should not be considered one of "jurisdiction" at all in view of the other burdens of meaning that word is obliged to carry. It is a question solely of the effect to be given a valid foreign judgment, and the common practice of attempting a solution in terms of "juriscliction" leads only to confusion. In a recent article on Jurisdiction and Foreign Judgments, Professor Nussbaum observed:

"Where recognition of a foreign judgment is prayed for, it is in reality not 'jurisdiction' of the foreign court which has to be determined by the forum. The forum can never confer jurisdiction upon or take it away from a foreign court. The foreign court derives jurisdiction from its domestic law and no other. What the forum actually does amounts to testing, in the forum's own terms, a requirement for granting territorial expansion to the res judicata effect of the foreign judgment." 5

Professor Nussbaum, however, finds no convenient term to substitute for the overworked word "jurisdiction" in testing the extraterritorial effect of foreign judgments. He adopts the terminology of Bartin, French systemizer of international procedural law, and distinguishes between jurisdiction in the sense of power of a court to determine a controversy within the state of the forum, which he calls "direct jurisdiction," and tests for the recognition of a judgment rendered in another state or country, which he calls "indirect jurisdiction." This terminology, it is believed, does not clearly bring out the real importance of the distinction made. It seems preferable to abandon the term "jurisdiction" entirely when referring to the problem of extraterritorial recognition of valid judgments. The distinction itself, however, is significant, and is especially helpful in evaluating the decisions on extraterritorial effect of probate

5. Nussbaum, Jurisdiction and Foreign Judgments (1941) 41 CoL. L. REv. 221, 224-25. 
decrees; for they frequently contain confusing language about "jurisdiction" when the real problem is not the validity of the foreign judgment in the state where rendered, but its effect, if any, in a local proceeding."

The decisions, in fact, reveal two contradictory general theories concerning extraterritorial recognition of probate decrees. One, with acknowledgment to Mr. Justice Holmes, may be called the physical power theory; the other, which that jurist no doubt would have considered more civilized, is an application of the maxim mobilia sequunlur personam. The premise of the physical power theory is the undoubted control which a state may exercise over things within its boundaries. If this power is fully asserted, it precludes the unified administration of a decedent's estate where the decedent's property is located in more than one state; and the property in each state becomes, in effect, a separate estate. Under this view, whether a proffered will has been admitted to probate or rejected in another state is a matter of no moment. The foreign decree is entitled to no recognition, for it cannot bind property outside the state where entered. A court following this line of reasoning would undoubtedly say that the foreign court had no "jurisdiction" to enter a decree witl respect to property in this state. It should be noted that implicit in this reasoning is the assumption that the res, or subject matter of the probate proceeding, universally recognized as a proceeding in rem, is the property belonging to the estate and situated within the state.

6. The unfortunate practice of speaking of "jurisdiction" as the power to decide a controversy in such a way that courts in other states will "generally" regard the judgment as conclusive is not restricted to probate cases. See Restatesiest, Co:ifuct of Laws (1934) \$ 42. In 2 PAGE, op. cit. stipra note 2 , at 37, it is said: "A state may assert power to decide the title to a thing and what disposition is to be made of it. It may assert power to make judgments, decrees, and the like, which can be enforced against the person who is indicated therein; or against his property in general. Such assertion of power is generally said to be a claim of jurisdiction. If other states and nations generally regard such judgments, orders, and decrees, as final and conclusive we say that the first state has jurisdiction. If the other states and nations generally refuse to give any effect to such judgments, orders, and decrees, we say that the first state has no jurisdiction. The existence and extent of jurisdiction thus depend rather on what the other states concede than on what the state in question claims. A state may clain much more than uther states are willing to concede. Its claim of jurisdiction may run far beyond its actual jurisdiction as determined by the general consent of the other states and nations." The diffculty with this definition is that, taken with the notion that a judgment is void if there is no jurisdiction, it leaves the inference that a "claim of jurisdiction" cannot be substantiated. The judgment, however, is not void within the state merely because other states will not recognize it as valid when brought into question in their courts. Despite that non-recognition, F-1 may effectuate the judgment upon local property as fully as though it had jurisdiction as there defined. Even with such jurisdiction it could do no more. Professor Nussbaum shows in detail that this unfortumate use of the word "jurisdiction" also exists in the Restatement. See Restatraneart, Cosfuct of Laws (1934) c. 4. Sec Nussbaum, supra note 5 . 
Under the other theory, the maxim mobilia sequnntur personam as applied to the administration of decedents' estates, it is possible to treat the entire estate, or at least the movables wherever situated, as a unit and to suppose it to be located in the state where the decedent was domiciled at the time of death. This maxim, at times, may be difficult of application. In the words of Judge Lehmann in Hutchison $\%$. Ross:

" 'The maxim mobilia sequuntur personam' cannot always be carried to its logical conclusion. Practical considerations often stand in the way. Physical presence in one jurisdiction is a fact, the maxim is only a juristic formula which cannot destroy the fact." 7

Like other legal fictions, this one was invented for a useful purpose ${ }^{8}$ and, although declining in importance in other conflict of laws situations, it retains a considerable following in decedents' estates cases. It is for that reason that an administration at the decedent's domicile is customarily referred to as the primary or principal administration, whereas all administration proceedings in other states are called ancillary administrations. Where this maxim is given extended recognition in determining the effect of a foreign probate decree, the court will concede to the state of decedent's domicile the primary authority or "jurrisdiction" to determine the question of testacy or intestacy, and proceed on the assumption that the function of the ancillary administration is to assist the court of the domiciliary administration in the handling of local property. Under this view, a foreign domiciliary decree will be held entitled to extraterritorial recognition so as to conclude the question of testacy or intestacy in F-2. Where this recognition is given, it is probable that the court will consider the res, or subject matter of the probate proceeding, to be the will itself,

7. 262 N. Y. $381,388,187$ N. E. 65,68 (1933).

8. The useful objective to be accomplished by the application of the maxim was eloquently expressed by Lord Chancellor Westbury in Enohin v. Wylie, $10 \mathrm{H}$. L. Cas. 1, 11 Eng. Rep. R. 924 (1862), a case involving construction of the will of a British subject who died domiciled in Russia owning personal property in England. In expressing his opinion that the English courts of probate and chancery should not have undertaken a construction of the will, the Lord Chancellor said:

"Now, the utmost confusion must arise if, when a testator dies domiciled in one country, the Courts of every other country in which he has personal property should assume the right, first of declaring who is the personal representative, and next of interpreting the will, and distributing the personal estate situate within its jurisdiction according to that interpretation. An Englishman, dying domiciled in London, may have personal property in France, Spain, New York, Belgium, and Russia; and if the course pursued by the Court of Probate and the Court of Chancery in the present case should be adopted by the Courts of those several countries, there might be as many different personal representatives of the deceased, and as many varying interpretations of his will, as there werc countries in which he was possessed of personal property.

"It is unnecessary to dwell on the evils which would result from this conflict of jurisdictions. It was to prevent them that the law of the domicile was introduced and adopted by civilized nations." Id. at 14, 11 Eng. Rep. R., at 930 . 
or the status of testacy or intestacy, rather than the property of the estate. ${ }^{9}$

The conflict between the maxim mobilia sequnntur personam and the physical power theory is by no means confined to the problem of the recognition of foreign probate decrees; it pervades the entire field of conflict of laws in administration of decedents' estates. Neither has gained a clear supremacy over the other, although it may be worthy of note that the Restatement of Conflict of Laws has emphasized, where possible, the application of the maxim. In an introductory note to the chapter on Administration of Decedents' Estates, it is said :

"There is another difficulty presented in the problem of administration, especially as among the States of the United States. An estate as a whole is, for practical purposes, a single thing, whether the items of property which compose it are all within the borders of one State or are scattered among several. But our States are for most purposes entirely separate legal sovereignties. It is difficult to administer an estate as a unit, if that portion of it in each state is to be treated as a completely separate affair.

"The treatment in this Chapter has emphasized the unitary character of the administration of an estate. It is believed that this is in accordance with both the trend of the decisions and administrative practice, and that it is highly convenient. Direct case authority cannot be cited for all the statements made. But the rules here set out are supported, it is thought, either by the decisions or by fair implications from the decisions especially those of the last half century." 10

The present inquiry, similarly, is directed toward the formulation of conflict of laws rules more nearly limiting wills contests to the state of

9. Professor Carey has elaborated these conflicting notions as to the identity of the res in probate proceedings, which are everywhere conceded to be in rem. See Carey, supra note 2 , at 49 . The notion that jurisdiction in rem attaches to the status of testacy or intestacy finds a ready analogy in divorce cases where it is usual to speak of the marital status as the res. It seems to the writer unnecessary and confusing to extend the coneeption of jurisdiction in rem usually applied to physical property so as to include a relationship or status. The explanation for this unfortunate terminology would seem to be the historical distinction in our law between jurisdiction in personam and in rem, and the desire to sustain a claim to jurisdiction in these cases without the necessity of personal service of process. It would have been more realistic simply to say that the appropriate court has jurisdiction to determine status without the necessity of personal service Sce Restateñent, Judgarents (1942) \$33. For the view that, although it is not helpiul to label divorce proceedings as proceedings in rem, a divorce decree is more than an ordinary in personam judgment, and that domicile of the plaintiff is an adequate jurisdictional basis for the decree so as to require its extraterritorial recognition even in the absence of personal service upon defendant, see Mr. Justice Douglas' opinion in Williams v. North Carolina, 317 U. S. 287 (1942).

10. Restatenent, Conflict of Laws (1934) c. 11, 560. 
the decedent's domicile rather than encouraging a separate contest in each state where property is left. It is not a question of the power or "jurisdictión" each state may assert over property within its boundaries. Rather, it is a question of how each state, in the exercise of that admitted power, may contribute to a convenient and unified administration of the entire estate by taking properly into account an important foreign element in the case, namely, the fact that a will affecting local property has already been admitted to probate, or rejected, by a court at the domicile.

Although most of the cases which have given extraterritorial recognition to the domiciliary decree have relied upon the maxim mobilia sequnntur personam, it seems unnecessary in justification of that result to resort to the fictional supposition that local property is situated in the foreign state. In most instances recognition may readily be justified through application of familiar principles of res judicata. ${ }^{11}$ This is especially obvious as to parties in F-2 who were also subject to the jurisdiction of F-1 in personam when the F-1 decree was entered, and as to property subject to F-1 jurisdiction in rem which was later removed to F-2. The most difficult situation in which to justify recognition through principles of res judicata is the case of property at all times in F-2, the claimants to which were not subject to F-1 jurisdiction in personam. Even in this situation, however, there is a judicially recognized principle of res judicata which justifies recognition of the domiciliary decree. This principle, as phrased in the Restatement of Judgments, is that "In a proceeding in rem with respect to a status the judgment is conclusive upon all persons as to the existence of the status." 12 In certain cases it is said that a probate proceeding is one in rem to determine the status of testacy or intestacy, and that a court at the domicile is primarily the appropriate forum for determination of that status. Although this analogy is not complete, the issue involved in such a matter as this is similar to that involved in a question as to the status of an individual, and, like a ju-

11. For a recent statement of res judicata principles see RESTATEMENT, JUDGMENTS (1942) c. 3. Although the Restatement deals primarily with the effect of a judgment in the state in which it was rendered, and only incidentally with its effect in other states, the principles of res judicata are applied generally when a foreign judgment is in question. In most instances the full faith and credit clause of the Constitution requires their application, but, where it does not, they may be applied uncler the conflict of laws rules in $F-2$.

12. Restatenent, JUDGMents (1942) \$74. In a comment upon this section it is stated: "Where in a proceeding for the creation or termination or judicial determintion of a status a competent court has after proper notice given a valid and final judgment, the judgment is binding on all persons in the world as to the existence of the status. The judgment is not subject to collateral attack by anyone, unless the judgment was void because the court did not have jurisdiction over the status or was not competent to render the judgment or there was a failure to give proper notice and opportunity to be heard. As far as the status is concerned, the judgment is binding not only on persons who were subject to the jurisdiction of the court which rendered the judgment, but also on persons not personally subject to the jurisdiction of the court." 
dicial determination of status, a juclicial determination of testacy or of intestacy by a court at the domicile may be deemed binding on persons not parties to the proceedings. The cases in which this analogy is accepted make no distinction as to the type of foreign domiciliary decree involved. Probate in common form, although strictly ex parte in nature, is a judicial establistment of testacy, and courts in other states may accept it as conclusive unless or until it is set aside in the appropriate proceeding in the state where made. Many F-2 courts, in fact, have used the term "c.x parte probate" loosely so as to include not only probates in common form. but also solemn form F-1 probates, with citation of parties, where neither the property in contest in F-2 nor the contestants in F-2 were actually before the F-1 court. The usage, although it combines two matters which at times might need to be distinguished, will be adopted in this discussion because of the convenience of having a single term to identify F-1 probates, regardless of type, where neither property nor contestants in $\mathrm{F}-2$ were before F-1. The next section is concerned primarily with the application of the full faith and credit clause of the Constitution to situations of this kind.

\section{Effect of the Full Fatth and Credit Clause}

The leading case in this country giving an extended application to the maxim mobilia sequntur personam, so as to require full extraterritorial recognition of a domiciliary probate decree, is Crippen $\boldsymbol{z}^{\prime}$. Dexter, ${ }^{13}$ decided in Massachusetts in 1859. In his opinion in that case, Chief Justice Shaw sought to place behind the maxim the compulsion of the full faith and credit clause of the Federal Constitution. ${ }^{14}$ His reasoning, in fact, was broad enough to include non-domiciliary foreign decrees as well as domiciliary ones, although a domiciliary decree was actually in question. The decedent died domiciled in Connecticut owning Massachusetts land. The will was probated in common form in Connecticut, and then offered for probate in Massachusetts upon authenticated copy of the foreign probate as permitted by statute. The heir at law, residing in Massachusetts, had no notice of the Connecticut proceeding; and he objected to the Massachusetts probate on a number of grounds, including undue influence in the procurement of the will, lack of testamentary capacity, and irregularities in the Connecticut proceedings. In denying the privilege of contest, the Chief

13. 79 Mass. 330 (1859).

14. U. S. CoNst. Akr. IV, §1: "Full Faith and Credit shall be given in each State to the public Acts, Records and judicial Proceedings of every other State. And the Congress may by general Laws prescribe the Mamner in which such Acts, Records and Proceedings shall be proved, and the Effect thereof." See 28 U. S. C. A. (1928) §687. The possibility should be noted that Congress might use the power granted in this clause to prescribe specifically the extraterritorial effect of problate decrees, improbable though such action may be. 
Justice reasoned that the judgment of a probate court allowing probate of a will, a proceeding in rem, is binding upon the rights of all persons interested in the property, though not named as parties. This disposed of the heir's contention that the Connecticut proceeding was invalid becaltse the statutes there did not provide for notice to the heirs. The Chief Justice said that making proof of a will in a court having "jurisdiction" of the subject matter determines the status, or condition, of the decensed's estate. It must be settled as an estate, testate or intestate. The establishment of one necessarily excludes the other. The Connecticut decree established the fact of testacy, and that decree was conclusive of the matter in Massachusetts by virtue of the full faith and credit clause of the Federal Constitution. The local court could inquire only into the due authentication of the foreign record, the jurisdiction of the foreign court, and whether there was local property upon which the will could operate if admitted. It was suggested also that perhaps actual fraud in obtaining the foreign probate might be open to question.

Since this decision has had a considerable influence in other states, it seems advisable to bring out another factor in the decision. The Massachusetts statutes permitting probate on authenticated copy of a foreign probate proceeding made no specific provision as to the grounds, if any, upon which a contest might be filed, but they did provide that a will executed abroad should have the same effect as a domestic will if executed in accordance with the laws of the state where executed. This is a modification of the common law choice of law rules under which the validity of a will of personal property is governed by the law of the decedent's domicile and a will of real property by the law of the situs. The problem of choice of law, as indicated above, is analytically distinct from the question of effect of foreign judgments, but the two may become closely related for practical purposes. If, for example, the common law rule as to personalty prevails at the forum and the court is to test the validity of a non-resident's will under the substantive rules prevailing at the domicile, it is probable the court will accept a domiciliary probate decree as an authoritative interpretation and application of that law. On the other hand, if there is real property rather than personalty involved, and again the common law rule is assumed, the foreign domiciliary probate decree will give little or no indication whether the formal requirements of the local Wills Act have been complied with, and that question would be open. But in all probability, the court will not confine the contest to questions of formal validity under local statutes. Less localized problems such as testamentary capacity, undue influence, and forgery of the will may be held open to investigation even though fully litigated at the domicile. Thus, choice of law rules are likely to have an important influence upon the effect which will be given to a foreign probate judgment, and in Crippen v. Dexter the statute estab- 
lishing reference points in addition to the law of Massachusetts for rules of law under which a will of Massachusetts land could be held valid, namely, the law of any state in which the will was executed, served to broaden the outlook as to the effect of a foreign probate decree. Chief Justice Shaw said:

"This statute does not in terms apply to a will made and proved in any other state or country; but with other acts of legislation it tends to confirm a general course of policy, to consider one effectual probate of a will, whether in our own or in a foreign state, according to the laws of such state, as conclusive and effectual, to all purposes." 15

Thus there are in this opinion two distinct grounds or reasons for the extraterritorial recognition of the Connecticut probate, and they should not be confused. One is a local Massachusetts policy, confirmed though not required by its statutes, to encourage a unified administration by adopting a conflict of laws rule recognizing foreign probate decrees as conclusive, even though a Massachusetts decree might not receive similar recognition elsewhere. The other is the supposition that once a will has been probated in any state having jurisdiction to do so, either because of property or domicile of the decedent within the state, the question of testacy or intestacy is concluded in every other state under the compulision of the Federal Constitution. Had the latter argument received the sanction of the United States Supreme Court, the problem here under consideration would have been reduced to a relatively simple rule of constitutional law rather than have remained a confused and difficult problem of conflict of laws. ${ }^{16}$ But the Supreme Court, in fact, has never yet enforced the rule of Crippen v. Dexter as a rule of constitutional law; it has so far left each state free to assert its full power over local property in disregard of foreign probate judgments, if it sees fit to do so, although in most of the cases where the constitutional issue was raised, there was also a failure to comply with the filing, ancillary probate, or other procedural requirements of

15. Crippen v. Dexter, 79 Mass. 330, 332 (1859).

16. There has been much excellent discussion of federal cunstitutiunal cuntrol uver conflict of laws. See, e.g., Dodd, The Pocier of the Supreme Court to Recicie Stafe Decisions in the Field of Confict of Law's (1926) 39 Hanv. L. REv. 533; Hilpert and Cooles, The Federal Constitution and the Choice of Lazo (1939) 25 Wasn. U. L. Q. 27; Ross, Has the Conflict of Laws Becone a Branch of Constitutional Law? (1931) 15 Mins. L. Rev. 161 ; Smith, The Constitution and the Confiet of Lanes (1939) 27 Gro. L. J. 536. Although those articles are concerned primarily with constitutional contrul vier state decisions on choice of law problems through a more extended application uf the due process and full faith and credit clauses, the possibilities visualized are equally pertinent to questions of the effect of foreign judgments. The Supreme Court could undoubtedly clarify the extraterritorial effect of foreign probate decrees by adopting the reasoning of Crippen v. Dexter, 79 Mrass. 330 (1859), but its past decisions on the subject give no indication that it is likely to do so. 
F-2.17 Several of these Supreme Court decisions involved conflicting adjudications as to decedent's domicile so that each state claimed to be the proper place for primary administration. ${ }^{18}$ In each case the Court rejected the argument that the full faith and credit clause required that the first such adjudication be respected in the second state. The reasoning was succinctly stated in one of the cases as follows:

"Now a judgment in rem binds only the property within the control of the court which rendered it . . . as a judgment in rem it merely determined the right to administer the property within the jurisdiction, whether considered as directly operating on the particular things seized, or the general status of assets there situated." 10

The Court also relied upon the well established rule that the full faith and credit clause does not preclude an inquiry into the "jurisdiction" of the court which rendered the judgment in question. This rule is sometimes applied in testing the validity of the foreign judgment in the state where rendered, since, of course, a judgment invalid where rendered is entitled to no credit elsewhere. But as used here the rule may assume the validity of the foreign judgment where entered; the question is merely whether the second forum will recognize it as binding upon local property. ${ }^{20}$

Another Supreme Court case bears out in inverse fashion the application of the full faith and credit clause to the "physical power" theory of extraterritorial recognition. In the cases discussed above, the Court refused to compel the state of the situs to respect a foreign adjudication; in Tilt $v$. Kelsey ${ }^{21}$ the court required that an adjudication at the situs be

17. Darby's Lessee v. Mayer, 10 Wheat. 465 (U. S. 1825), holds that a Maryland probate record is not required to be accepted under the full faith and credit clatuse as evidence of title in an ejectment action in Tennessee; McCormick v. Sullivant, 10 Wheat. 192 (U. S. 1825), holds that no claim to Ohio lands could be founded upon a will probated in Pennsylvania but not probated in Ohio; accord, Robertson v. Pickrell, 109 U. S. 608 (1883). In Blount v. Walker, 134 U. S. 607 (1890), a will exercising a power of appointment was probated at the domicile in North Carolina, and later, exemplified copies were filed in South Carolina where land subject to the power was situated; it was held that the full faith and credit clause did not preclude South Carolina from determining the validity of the will under its own laws, even though it was assumed the will was valid in North Carolina as to property there. In Clarke v. Clarke, 178 U. S. 186 (1900), the domiciliary decree construed a will as having accomplished an equitable conversion of land wherever situated, but it was held that the courts of another state where a portion of the land was situated did not deny full faith and credit when they placed a contrary construction upon the will.

18. Riley v. New York Trust Co., 315 U. S. 343 (1942) ; Baker v. Baker, Eccles Co., 242 U. S. 394 (1917); Overby v. Gordon, 177 U. S. 214 (1900); Thormann v. Frame, 176 U. S. 350 (1900).

19. Thormann v. Frame, 176 U. S. 350, 355 (1900).

20. The uncertainty as to situs of intangibles for purposes of al'ministration has been discussed by the present author elsewhere. See Hopkins, Confict of Lanes in Administration of Decedents' Intangibles (1943) 28 Iowa L. REv. 422, 613.

21. 207 U. S. 43 (1907). 
respected when challenged elsewhere. The testator had lived both in New Jersey and in New York; his domicile at time of his death was in dispute. The will was probated in New Jersey as a domiciliary proceeding. The bulk of the estate consisted of bank deposits and other credits in New Jersey, and stock in New Jersey corporations. Whether any of the property was situated in New York at the time of death does not clearly appear from the opinion; but, in any event, it was all brought under the possession and control of the executor in the New Jersey proceeding and distributed there. Thereafter, a New York proceeding was instituted for the collection of a succession tax, and upon a finding that the testator was a resident of New York the tax was imposed. The executor carried the case to the United States Supreme Court claiming a denial of full faith and credit to the New Jersey proceeding. The Court held that, while that proceeding was not conclusive in New York on the question of domicile, it was conclusive so far as property in New Jersey was concerned; under New Jersey law the property there had been distributed free from the claims of creditors or others, whether parties to the proceeding or not, and for the New York court now to attempt to assert a lien upon such property or to establish a personal liability upon the executor or distributees would be a denial of full faith and credit to the New Jersey judgment.

These cases make it clear that the Supreme Court has adopted the physical power theory, rather than the maxim movilia sequuntur personam, insofar as the full faith and credit clause is applicable in determining the extraterritorial effect of probate decrees. As to property within the territorial limits of F-1 when the decree was entered, full faith and credit is required elsewhere. As to property not within those limits, the full faith and credit clause has no application, at least to the extent the F-1 decree operates in rem, which is the situation here under consideration. The possibility of constitutional compulsion as to persons who were subject to F-1 jurisdiction in personam will be considered in the next section.

As long as the Supreme Court continues to interpret the full faith and credit clause in such a way that each state may disregard the probate decrees of sister states in dealing with the decedent's local property, any state judgment giving extraterritorial recognition to a foreign probate decree must rest upon a local conflict of laws rule rather than upon constitutional compulsion. This fact has been fully recognized in the great majority of state cases in which the full faith and credit clause has been an issue, and courts have asserted full dominion over local property, both real and personal, in disregard of foreign decrees. ${ }^{22}$ Nowhere is the

22. See Frederick v. Wilbourne, 198 Ala. 137, 73 So. 442 (1916); State cx rel. Atty General v. Wright, 194 Ark. 652, 109 S. W. (2d) 123 (1937) (full faith and credit required where property was all in F-1 rather than at the forum); Schweitzer v. Bean, 154 Ark. 228, 242 S. W. 63 (1922); Selle v. Rapp, 143 Ark 192, 220 S. W. 662 (1920); In re Reynolds' Estate, 217 Cal. 557, 20 P. (2d) 323 (1933); Foster v. Kragh, 
rationale of these decisions more clearly stated than in a Rhode Island decision, a contemporary of Crippen r. Dexter; the court stated with reference to a sister-state decree:

" 'Full faith and credit' is given to it abroad, when the same faith and credit is given to it which it has at home; and that is, that it is to be conclusive evidence of the validity of the will, as affording title to things within the jurisdictional limits of the court at the death of the testator, whether such title comes in contest within or without those limits; but, de jure, no evidence whatever of title to things not then within those limits." 23

Early state decisions reaching a contrary result through a false reliance upon the full faith and credit clause have been largely overruled or abandoned. ${ }^{24}$ In a few decisions it has been supposed that full faith and credit is required to be given to a domiciliary decree as to personal property wherever situated, ${ }^{25}$ but not as to real property. This distinction results from confusion of the choice of law problem with that of the effect of foreign judgments, and the spurious supposition that since, under the common law rule, disposition of personal property on death depends upon the law of the domicile, a decree of the domiciliary court must be respected as to personal property in other states. But, as pointed out above, the United States Supreme Court has not embraced the maxim mobilia sequnntur personam as a rule of constitutional law as to either type of

107 Colo. 389, 113 P. (2d) 666 (1941); New York Trust Co. v. Riley, 16 A. (2d) 772 (Del. 1940), aff'd, 315 U. S. 343 (1942); Trotter v. Van Pelt, 144 Fla. 517, 198 So. 215 (1940) ; Chidsey v. Brookes, 130 Ga. 218, 60 S. E. 529 (1908); Dibble v. Winter, 247 Ill. 243, 93 N. E. 145 (1910); Hofferd v. Coyle, 212 Ind. 520, 8 N. E. (2d) 827 (1937); Evansville Ice \& Cold Storage Co. v. Winsor, 148 Ind. 682, 48 N. E. 592 (1897) ; Stillivan v. Kenney, 148 Iowa 361,126 N. W. 349 (1910) ; Hines v. Hines, 243 Mo. 480 , 147 S. W. 774 (1912) ; Keith v. Johnson, 97 Mo. 223, 10 S. W. 597 (1889); The Trust Co. of New Jersey v. Spalding, 125 N. J. Eq. 66, 4 A. (2d) 401 (1939); Nelson v. Potter, 50 N. J. L. 324, 15 At1. 375 (1888); In re Harriman's Estate, 124 Misc. 320, 208 N. Y. Supp. 672 (Surr. Ct. 1924), aff'd without opinion, 216 N. Y. Supp. 842 (App. Div., 1st Dep't 1926) ; Richards v. Huff, 146 Okla. 108, 293 Pac. 1028 (1930) ; Bowen v. Johu1son, 5 R. I. 112 (1858) ; Kirkland v. Calhoun, 147 Tenn. 388, 248 S. W. 302 (1922); Walton v. Hall's Estate, 66 Vt. 455, 29 Atl. 803 (1894); Frame v. Tharmann, 102 Wis. 653, 79 N. W. 39 (1899).

23. Bowen v. Johnson, 5 R. I. 112, 118-19 (1858).

24. Doe v. Roe, 31 Ga. 593 (1860), overruled by Chidsey v. Brookes, $130 \mathrm{Ga} .218$, 60 S. E. 529 (1908); Harris v. Harris, 61 Ind. 117 (1878), overruled as to land in Evansville Ice \& Cold Storage Co. v. Winsor, 148 Ind. 682, 48 N. E. 592 (1897); Hofterd v. Coyle, 212 Ind. 520, 8 N. E. (2d) 827 (1937); Martin v. Stovall, 103 Tenn. 1, 52 S. W. 296 (1899). But see Kirkland v. Calhoun, 147 Tenn. 388, 248 S. W. 302 (1923); Walton v. Hall's Estate, 66 Vt. 455, 29 At1. 803 (1894); Ives v. Heirs of Salisbury, 56 Vt. 565 (1883).

25. Evansville Ice \& Cold Storage Co. v. Winsor, 148 Ind. 682, 48 N. E. 592 (1897); Martin v. Stovall, 103 Tenn. 1, 52 S. W. 296 (1899); see Dibble v. Winter, 247 I11. 243, 93 N. E. 145 (1910). 
property, and most of the few states which persist in the contrary view likewise make no distinctions as to kind of property involved. ${ }^{20}$ The rationale of this minority group of cases differs slightly from that of Crippen v. Dexter. ${ }^{27}$ In that case Chief Justice Shaw seems to have supposed that the Constitution required full faith and credit be given to any sister-state decree whether domiciliary or merely founded upon the presence of property in the state, whereas these decisions are restricted to domiciliary decrees. The reasoning may be illustrated by a recent Texas decision in which the testator died owning real and personal property situated in both California and Texas. A will was probated in California in what purported to be domiciliary proceedings. Thereafter, in a proceeding in Texas for the probate of the will on authenticated copy of the California record, Texas claimants to the estate, who had no actual notice of the California proceedings, ${ }^{28}$ contested on the ground the will was a forgery. In holding that the full faith and credit clause prohibited the contest, the Texas Supreme Court said:

"It is fairly well settled by the weight of authority in this country, that jurisdiction of the original probate of a will is possessed exclusively by the courts of the state where the testator was domiciled when he died. When the will is regularly probated there, the constitutional provision under consideration requires all sister states to give full faith and credit to the order of probate as verifying the instrument. In such a case, the question of authenticity of the instrument would be res adjudicata; but the question as to the legal effect of the instrument would not be." ${ }^{20}$

Another leading state case of the minority group illustrates a further confusion of the choice of law problem with that of effect of foreign judgments in determining the effect of the full faith and credit clause.

26. Kurtz v. Kurtz's Estate, 169 MId. 554, 182 Atl. 456 (1936); State cr rel. Ruef v. District Court, 34 Mont. 96, 85 Pac 866 (1906); Hopper v. Nicholas, 105 Ohio St. 292, 140 N. E. 186 (1922) (full faith and credit was required of a foreign decree fixing domicile, but case is explainable on principles of res judicata since all persons interested in the estate had appeared in F-1, waived service, and consented to probate) : Grignon v. Shope, 100 Ore. 611. 197 Pac. 317 (1921) ; Holland v. Jackson, 121 Tex: 1, 37 S. W. (2d) 726 (1931) ; Hodge v. Taylor, 87 S. W. (2d) 533 (Tex. Civ. App. 1935).

27. 79 Miass. 330 (1859).

28. The Texas Supreme Court made no reference to the fact that the California proceeding was an ex parte probate as herein defined in which citation of interested parties was made by publication; this fact appears from the opinion of the Court of Civil Appeals, Holland v. Jackson, 19 S. W. (2d) 428 (1929), and is important in evaluating the decision of the Supreme Court. It means that the decision can not be sustained on the principle of res judicata in personam as would be the case had the Tevas claimants appeared in the California proceeding; it stands squarely for the untenable proposition that adherence to the maxim mobilia sequmntur personam as applied to ex farle F-1 probate decrees is compelled by the Federal Constitution.

29. Holland v. Jackson, 121 Tex. 1, 5, 37 S. W. (2d) 726, 727-28 (1931). 
Montana statutes had modified the common law choice of law rule so as to admit to probate in Montana on authenticated copy of foreign probate a will executed according to the law of the place of execution, or according to the law of the testator's domicile, or according to the law of Montana. A will probated in California, the domicile, was offered in Montana pursuant to these statutes, and was contested on grounds of undue influence, fraud, and want of testamentary capacity. The Montana Supreme Court held that the full faith and credit clause preclucled the contest. ${ }^{30}$ The decision rested in part upon construction of the Montana statutes, and might well have rested there exclusively. But a will originally admitted in Montana was subject to contest within a year after probate, and the statute provided that a will admitted on authenticated copies of foreign probate should have the same force and effect as a will first admitted in Montana. To overcome this difficulty the court reasoned that since the Californin judgment was conclusive in the state where rendered it must be considered conclusive in Montana even within the year after probate; otherwise, the fuil faith and credit clause would be offended. In answering the argument that the California court had no jurisdiction over Montana real estate, which is subject solely to the law of the situs, the court indulged in the non sequitur that, granting this to be true, the Montana statutes having established additional tests for validity in accordance with the rules prevailing at the domicile, a domiciliary probate decree is entitled to full faith and credit under the Federal Constitution. While the result reached in this case would seem desirable, it should rest upon a local conflict of laws rule as to the effect to be given to a foreign judgment rather than upon a spurious constitutional compulsion.

\section{Effect of the Doctrine of Res Judicata}

In the discussion thus far, little attention has been given to the difference in effect of the doctrine of res judicata depending upon whether the F-1 judgment may be permitted to operate in personam or must operate strictly in rem. Most of the cases heretofore discussed involved F-1 judgments founded upon probate proceedings to which the contestants in the F-2 proceeding were not parties, and in which their only notice, if any, was by publication. Fewer cases are to be found in which the parties to the F-2 proceeding were before the court in the prior case. The fact is, however, that a probate decree may be permitted to operate as a judgment in personam as to those who are parties to the proceeding and who appear therein or are properly served wtih process within the state.

This is not the place for an extended discussion of the difference between jurisdiction in personam and in rem, and whether that difference is

30. State ex rel. Ruef v. District Court, 34 Mont. 96, 85 Pac. 866 (1906). 
well founded on logical and philosophical grounds. ${ }^{31}$ It is a distinction well understood and acted upon by the legal profession, and our courts have long utilized it to determine and establish a wider range of legal regulations as to persons actually before the court or properly represented there than is considered permissible where jurisdiction over the controversy rests alone on the presence of property within the territorial limits of the court. Our question is whether the courts, pursuant to that distinction, give to probate judgments a wider extraterritorial recognition in cases where the parties to the $F-2$ proceeding were also before the $F-1$ court, so that the F-1 judgment may properly be said to operate in personam, than would be given to an F-1 decree of the type herein referred to as cx parle.

One of the prime requisites to application of the res judicata principle is identity of issues. For that reason, it is readily seen that a contest inter partes on a question of formal validity under the local WVills Act does not conclude the parties in a second contest in another state whose laws provide different formal requirements as to property there. The Wills Acts differ from state to state concerning details as to form of wills and the ceremony of their execution. These differences relate to such matters as permissibility of nuncupative and holographic wills, place of testator's signature, number and competency of witnesses, order of signing, and the like. Cases in F-2 involving such issues of formal validity may be conveniently distinguished from those in which less localized issues are presented, such as testamentary capacity, undue intluence, fraud, or forgery, which may be termed, for convenience, essential validity. On issues of essential validity the legal standards of the various states are likely to be substantially alike, and the cases usually turn on disputed facts. Similarly, in cases where the decedent's domicile is in dispute the issue is typically one of fact. Under those circumstances the $\mathrm{F}-2$ court usually will treat the issues in F-1 and F-2 as identical and preclude a second contest between the same parties. But the F-2 court may, however, adopt the power theory in extreme form, disregard the principles of res judicata, and deny that F-1 has "jurisdiction" to determine anything with respect to

31. In one of his brilliant critical articles, 7 he Jurisdiction of Soctrcign Statcs and The Confict of Lawes (1931) 31 CoL. L. REv. 368, Frofessor Cuok demonstrated that basic postulates on jurisdiction, in the conflict of laws sense, all tacitly assume another postulate, i.c., that jurisdiction can be exercised separately over persuns and over things, and that when exercised over one it does not involve at the same time an exercise of jurisdiction over the other. The fallacy Professor Cook finds in this assumptiun may ba illustrated by his example of a foreclosure action concerning land of a nonresident; it is impossible to create additional rights in the mortgagee with respect to the land without altering the rights of the nonresident mortgagor. Professor Cuok's pustulate is that rights . which relate to things are always rights against other persons, nut against the thing said to be owned. See also Restatearext, Prorerti (1936) intruduetury mute, 3: "The word 'property' is used in this Restatement to denote legal relations between persons with respect to a thing." 
property subject to $F-2$, even though the parties fully litigated the matter in question in $\mathrm{F}-1$.

Decisions in a few states have, in fact, adopted this extreme view. The rationale may be illustrated by a Delaware case. The testatrix died domiciled in Maryland owning Delaware real estate which she devised to the defendant. The will was contested in Maryland and rejected for undue influence. The heir at law, who was also appointed administrator by the Maryland court, then brought ejectment against the devisee. The devisee had not been a formal party to the Maryland contest, but he was present there and testified in support of the will, and it was contencled that he was represented by the executor who propounded the will, and he was estopped by the Maryland judgment from claiming validity of the will. In holding that the issue was not res judicata in Delaware the court said:

"For the purposes of this case, it is wholly immaterial whether the defendant in said action of ejectment was or was not a party to the said proceedings in Maryland. While the Maryland court had full jurisdiction to find that the alleged will, so far as it related to testator's personal property and her lands in Maryland, was procured by fraud and undue influence, and that she was not of sound and disposing mind and memory, it had no jurisdiction whatever to make a conclusive determination as to these facts, or any other facts touchthe validity or invalidity of the paper, so far as the same relates to the title to the land in Delaware. The defendant therefore is not estopped from denying in said action any or all of said findings of the Maryland court." 33

This extreme application of the power theory, however, must be regarded as a minority view. Most of the cases have considered contested issues, or issues necessarily passed upon though not contested, as to decedent's domicile or essential validity of a will, res judicata in F-2 on the

32. Frederick v. Wilbourne, 198 Ala. 137, 73 So. 442 (1916) (involving probate of inconsistent wills in different states; decision turns, in part, on fact that probate in F-2 preceded in time the contest in F-1); Pritchard v. Henderson, 2 Penn. 553, 47 Atl. 376 (Del. 1900) ; McCartney v. Osburn, 118 Ill. 403, 9 N. E. 210 (1886) (construction of will); Woodville v. Pizzati, 119 Miss. 442, 81 So. 127 (1919); In re Gaines' Will, 84 Hun. 520, 32 N. Y. Supp. 398 (Sup. Ct. 1895), aff'd without opinion, 154 N. Y. 747, 49 N. E. 1097 (1897) (issue of forgery); In re Neumayer's Estate, 168 Misc. 173, $5 \mathrm{~N}$. Y. S. (2d) 331 (Surr. Ct. 1938) (issue of testamentary capacity).

33. Pritchard v. Henderson, 2 Penn. 553, 563-64, 47 Atl. 376, 379 (Del. 1900). Cf. Roberts v. Bathurst, 112 F. (2d) 543 (C. C. A. 5th, 1940) (holding litigation by sole legatee binding upon representative of estate who was not a party). The question of conclusive effect of a judgment as to one not a party of record or privy to such a party, but

- who participated in the suit or was represented therein under the class suit doctrine, is too large for treatment here. For an extensive recent note on the subject, see (1942) $139 \mathrm{~A}$. L. R. 9. The problem has conflict of laws significance, however, because of the full faith and credit clause of the Federal Constitution. See discussion of Riley v. New York Trust Co., 315 U. S. 343 (1942) at pages 243-46 infra. 
theory that the judgment operates in personam as well as in rem upon all persons properly before the F-1 court. ${ }^{33}$ Considerations of policy and convenience point rather obviously to a preference for the majority view in this situation. One may suppose the case of a testator of doubtful testamentary capacity who dies owning property in several states and leaving heirs and devisees with a penchant for litigation; there is little to recommend a rule which invites a separate contest in each of the states where property is to be found.

There is a probability that this majority view need not rest alone on considerations of policy, but that compliance with it is required by the full faith and credit clause of the Federal Constitution. So far as the author has been able to discover the United States Supreme Court has not passed directly upon the point; but a number of its recent decisions on the subject of res judicata clearly show an expanding application of that principle, particularly as to issues of jurisdiction over the subject matter. Those decisions have provoked much comment in legal periodicals, ${ }^{35}$ and even a speculation that the strong policy of res judicata expressed in those cases demands that a determination of domicile in a probate proceeding be accorded full faith and credit elsewhere as to persons who were parties to the prior suit. ${ }^{36}$ Although not all of those recent cases on res judicata of an issue of jurisdiction over the subject matter actually turned on the full faith and credit clause, their persuasive application by analogy to the problem under consideration is apparent when it is recalled that at several points in the administration of an estate the decedent's domicile is a matter of crucial importance and that it is frequently said to be "jurisdictional

34. Willetts' Appeal, 50 Conn. 330 (1882) (decedent's domicile); Loewenthal v. Mrandell, 125 Fla. 685, 170 So. 169 (1936) (decedent's domicile); compare Torrey v. Bruner, 60 Fla. 365, 53 So. 337 (1910), with Trotter v. Van Pelt, 14t Fla. 517, 198 So. 215 (1940) ; Thomas v. Morrisett, $76 \mathrm{Ga} .384$ (1886) (decedent's domicile). Quinton v. Kendall, 122 Kan. 814, 253 Pac. 600 (1927) (construction of will) ; ALurphy v. Macliey, 135 Md. 611, 109 Atl. 326 (1920) (validity of will); Dalrymple v. Gamble, 68 Ard. 523, 13 Atl. 156 (1888) (testamentary capacity, undue influence, and construction of will); compare Ins re Fischer's Estate, 118 N. J. Eq. 599, 180 Atl. 633 (1935) (decedent's domicile), with The Trust Co. of New Jersey v. Spalding, 125 N. J. Eq. 66, 4 A. (2d) 401 (1939) (res judicata as to persons not represented before the F-1 court denied) ; In re Barney's Will, 94 N. J. Eq. 392, 120 Atl. 513 (1923) (issue of testamentary capacity, and executor proponent in F-1 held to represent legatees so as to bind them in F-2, although they were not formal parties in F-1) ; Hopper v. Nicholas, 106 Ohio St. 292, 140 N. E. 186 (1922) (decedent's domicile) ; In re Hunter's Estate, 190 Olik. 284, 122 P. (2d) 1017 (1942) (decedent's domicile); see Restatenent, Conflict of Laws (1934) $\S 470(3)$.

35. See especially Boskey and Braucher, Jurisdition and Collatcral Allacl:: October Term, 1939 (1940) 40 CoL. L. KEv. 1006; (1939) 39 CoL L. KEv. 274; (1939) 27 GEO. L. J. 1137; (1939) 23 Minn. L. Rev. 673; ( 1939) 17 TEx. L. Rev. 485; (1939) 6 U. OF CHI. L. REv. 293.

36. Boskey and Braucher, supra note 35, at 1013-14. 
fact." ${ }^{37}$ The rationale of this whole series of cases was succinctly stated in one of the decisions involving an inter partes contest in Idaho on an issue of the jurisdiction of a Washington court under its own laws, in which the Idaho court found the Washington judgment invalid. No effective appeal was taken from the Idaho judgment. After it became final the controversy came into the federal courts on interpleader under the federal act; and in an opinion by Mr. Justice Reed sustaining the Idaho judgment the Supreme Court said:

"Even where the decision against the validity of the original judg" ment is erroneous, it is a valid exercise of judicial power by the second court.

"One trial of an issue is enough. The principles of res judicata apply to questions of jurisdiction as well as to other issues, as well to jurisdiction of the subject matter as of the parties." 38

The general effect of these decisions, through an expanding application of the res judicata principle, is to curtail the application of the dogma that

37. As already pointed out, the statement that domicile is a jurisdictional fact in probate matters is somewhat misleading, since it is universally conceded that presence of property in a state is a factor warranting a local administration. Domicile is a jurisdictional fact only in the rare case where there is no property in the state of administration. Domicile, however, is important in determining the extraterritorial effect to be given to a foreign probate judgment under the conflict of laws rule of the forum. It may also be important in determining choice of law and other problems arising in an administration proceeding, including whether probate in $\mathrm{F}-2$ should be an original proceeding or made pursuant to a statute permitting probate on authenticated copy of an F-1 proceeding, and whether local assets should be transmitted to another state for distribution at the domicile. Since the maxim mobilia sequntutur personam is in fact extensively applied for various purposes in administration proceedings, the decedent's domicile is a matter of paramount importance. But, with very few exceptions, it is not a jurisdictional fact in the sense of determining the validity of a judgment in the state where rendered. Statutes fixing local jurisdiction to grant letters of administration frequently provide for such power in a court of the county or territorial district where decedent was domiciled at the time of his death, without regard to the place of his death or the situs of his property. It was formerly held in many states that a finding and adjudication that such domicile existed was subject to collateral attack, but nearly all states now hold to the contrary. 2 Woerner, The American Law of Aduinistration (3d ed. 1923) 672. During the last decade the decedent's domicile also became a jurisdictional fact, for the limited purpose of determining state power to levy an inheritance tax upon intangible assets. But under the latest pronouncement of the Supreme Court on that vexed question it is held that the Fourteenth Amendment no longer confines such taxing power to the state of domicile, and that any state which has extended benefits or protection or which can demonstrate "the practical fact of its power" or sovereignty as respects the asset may likewise constitutionally make its exaction. State Tax Commission of Utah v. Aldrich, 316 U. S. 174 (1942).

38. See Treinies v. Sunshine Mining Co., 308 U. S. 66, 78 (1939). Other important cases in the series are: Chicot County Drainage District v. Baxter State Bank, 308 U. S. 371 (1940) ; Stoll v. Gottlieb, 305 U. S. 165 (1938); Davis v. Davis, 305 U. S. 32 (1938) (full faith and credit clause). For detailed analysis, see Boskey and Braucher, supra note 35 . 
in an F-2 proceeding the jurisdiction of the F-1 court is always open to inquiry. It is no longer open to inquiry if the issue of jurisdiction over the subject matter was contested inter partes in F-1. The rule had been theretofore established as to contested issues of jurisdiction over the person. ${ }^{39}$ That this recently expanded principle of res judicata will be enforced upon the state courts under the full faith and credit clause is made reasonably certain by two Supreme Court decisions. ${ }^{20}$ That it will include issues necessarily passed upon, although not fully litigated in $F-1$, is indicated by a third, ${ }^{41}$ provided the same cause of action is involved in F-2 so that the res judicata principle may be invoked in bar rather than as a collateral estoppel.

As applied to the problem here under consideration, the above developments in Supreme Court doctrine point to the following results. Where, in an $F-1$ probate proceeding, a finding is made as to decedent's domicile, that finding must be respected in F-2 as to all persons who were parties to the F-1 proceeding and properly before the court, even though domicile be

39. See Baldwin v. Iowa State Traveling Men's Ass'n, 283 U. S. 522 (1931); REStATEareNt, CONFLict of LAws (1934) \$451 (a cas'rat to this section carefully refrains from any opinion as to whether res judicata should preclude relitigation of an issue of jurisdiction over the subject matter) : Boskey and Braucher, sufra note 35. In (1939) 27 GEo. L. J. 1137, it is noted that the tightening effect of res judicata is not applied in eases of extrinsic fraud in obtaining the F-1 judgment, nor in cases of gross denial of constitutional rights.

40. Davis v. Davis, 305 U. S. 32 (1938); American Surety Company v. Baldwin, 287 U. S. 156 (1932). Neither case involved an F-2 state judgment directly reviewed in the Supreme Court for denial of full faith and credit, but in each ease a state judgment was collaterally attacked in an independent proceeding in a federal court, and full faith and credit was required to be given to the state adjudication of jurisdictional fact. As the Court said in the American Surety case, id. at 160: "The full faith and credit clause, together with the legislation pursuant thereto, applies to judicial proceedings of a state court drawn in question in an independent proceeding in the federal courts."

41. Chicot County Drainage District v. Baxter State Bank, 308 U. S. 371 (1940). Pursuant to the Mfunicipal Debt Readjustment Act of 1934, 48 Sras. 798, a federal district court entered a final decree approving a plan of readjustment of the indebtedness of the Chicot County Drainage District. The decree cancelled the defaulted bonds of the District, and enjoined the bondholders from enforcing their claims except as provided in the plan. No question of the validity of the statute was raised. Suvn thereafter the Supreme Court held the statute unconstitutional in Ashton v. Camerun County Water Improvement District, 298 U. S. 513 (1936). Subsequently, certain bundltolders of the Chicot County Drainage District who were parties in the readjustment proceeding, but who had not appeared therein, brought action on their bunds in the same federal court which had decreed the readjustment. The district court and the circuit court of appeals rejected the defense of res judicata on the ground that jurisdiction of the banliruptcy court depended upon an unconstitutional statute, and that the prior decree was void. The Supreme Court reversed, and held that the defense of res judieata may tre pleaded as a bar not only as respects matters actually presented to sustain or defeat the right asserted in the prior proceeding, but also as respects any other available matter which might have been presented to that end. 
considered a jurisdictional fact. ${ }^{42}$ As to such persons, all factual determinations pertinent to such issues as substantial validity of a will must be likewise conclusive in F-2. In either case, of course, it must be assumed that such parties are concluded on the particular issue in F-1, for no greater credit is required elsewhere of a judgment than it has where rendered. ${ }^{43}$

These conclusions could be vitiated, to be sure, if the Supreme Court should accept the reasoning in the minority of state decisions discussed above and hold that no F-1 judgment can have any effect upon property contested in F-2, even though the parties were before the first court. A1though, as has been pointed out heretofore, the Supreme Court has adopted the power theory in determining the effect of the full faith and credit clause where the F-1 decree operates only in rem, it has not yet applied that theory with its limiting consequences to the case of an F-1 decree operating in personam. It seems highly probable that such an application will be made, for it would constitute a virtual denial that a probate judgment can operate as a judgment in personam as well as in rem; and in two of its leading decisions on full faith and credit in the probate field the Court clearly recognized that possibility. Both cases involved conflicting adjudications of domicile. In the first, Baker v. Baker, Eccles \& Company, ${ }^{44}$ the intestate died owning shares in a Kentucky corporation and a claim against the corporation for profits. If this property were distributed under Tennessee law, the widow would take it all; if distributed under Kentucky law, one-half would go to intestate's mother. The widow opened an administration in Tennessee, the ex parte order

42. See note 37 stipra.

43. Robertson v. Pickrell, 109 U. S. 608, 610 (1883): "The act of Congress declaring the effect to be given in any court within the United States to the records and judicial proceedings of the several states, does not require that they shall have any grenter force and efficacy in other courts than in the courts of the States from which they are taken, but only such faith and credit as by law or usage they have there." In considering the effect of a judgment in the state where rendered it should not be overlooked that a probate decree may not always enjoy the same immunity to collateral attack as judgments of other courts. The historical development in the status of probate courts in the United States has been toward a similar conclusiveness, but in some states a divergence still remains. See 1 Woerner, The American Law of Administration (3d ed. 1923) 488. Another important distinction should not be overlooked. The principle of res judicata has two aspects, one as a bar, the other as a collateral estoppel. A judgment is a bar against the prosecution of a second action upon the same cause of action, and is conclusive not only as to every matter which was offered and received to sustain or defeat the claim or demand, but as to any other admissible matter which might have been offered for that purpose. Where, however, the second suit between the same parties is upon a different cause of action, the judgment in the prior suit operates as an estoppel only as to matters actually litigated and determined, not as to what might have been litigated. Cromwell v. County of Sac, 94 U. S. 351 (1876) ; see Scott, Collateral Estoppel by Judgment (1942) 56 HARv. L. REv. 1. For that reason it is necessary to determine precisely what was litigated by an F-1 judgment when it is brought into question in F-2.

44. 242 U. S. 394 (1917). 
reciting that intestate was a resident of that state. The widow then sought to fortify her position by a chancery suit in Tennessee against the mother and the corporation, in which defendants were cited by publication only and did not appear, and procured an adjudication that she was owner and distributee of the shares and entitled to have new certificates issued to her. Meanwhile, the mother had opened an administration in Kentucky and procured a decree finding that the intestate died a resident of that state and that the property should be divided according to Kentucky law. The widow then sued the corporation in Kentuchy claiming the entire property in reliance upon the Tennessee judgments; the mother intervened and claimed her one-half interest under the Kentuchy judgment. Upon the denial of her claim the widow took the case to the United States Supreme Court alleging a denial of full faith and credit to her Tennessee judgments. In affirming the Kentucky judgment, the Supreme Court recognized the distinction between the effects of a judgment in its operations in personam and in rem. As judgments in rem the Tennessee findings were said to be conclusive only as to property in Tennessee, and this property was legally situated in Kentucky. As judgments in personam the Tennessee findings were invalid for want of due process of law where defendants were not properly before the court. The Supreme Court said that a single controlling decision upon the question of domicile would be impossible "unless all possible distributees ... [could] be brought within the jurisdiction of a single court having authority to pass upon the subject-matter, either by service of process or by their voluntary appearance," ${ }^{4 \bar{J}}$ despite the inconvenience of a failure to secure the ideal distribution of the entire personal estate as a unit.

The second of these cases, Riley i'. Nou' York Trust Co., ${ }^{20}$ is the latest pronouncement of the Supreme Court on constitutional control over extraterritorial recognition of probate decrees, and it deserves careful analysis, not only for that reason, but, as the Court said in explaining the grant of certiorari, "because of the importance of issues previously undecided by this court. ..." 47 The will of the testatrix was probated in Georgia, as a domiciliary probate, with all persons entitled under Georgia law to be heard, including her husband, actual parties by personal service. A special finding of Georgia domicile was made over the husband's objection, and was approved, as an essential fact to determine jurisdiction, by the highest court of Georgia in affirming the probate. Meanwhile an independent administration was opened in New York, which state was also asserted to be the domicile, and, at the suggestion of the testatrix' husband and the state tax commission, the New York Trust Co. was ap-

45. Id. at $40+05$.

46. 315 U. S. 343 (1942).

47. Id. at 348 . 
pointed administrator c.t.a. Although the husband was before the New York court, the heirs, beneficiaries of the will, and the Georgia executor did not appear and were served only by publication or by stubstituted service in Georgia. At the time of her death the decedent owned certain shares of stock in the Coca Cola International Corporation. The administrator and the executor, each claiming to be the domiciliary representative, asserted the right to have new certificates representing the shares issued to him. The corporation was fortunate enough to get both representatives before a Delaware court of chancery on a bill of interpleader, where they agreed that Delaware was the situs of the stock. The Delaware court made an independent determination of domicile, and on the record it was held in the Delaware Supreme Court that the testatrix was domiciled in New York and that the corporation should issue new certificates to the New York administrator. The question on certiorari was whether Delaware had denied full faith and credit to the Georgia judgment. The Court held it had not. In the opinion, delivered by Mr. Justice Reed, we have the clearest expression by the Court to date of the difference in impact of the doctrine of res judicata depending upon whether the probate decree in question operates strictly in rem or whether it may be permitted to operate in personam. He said:

"While the Georgia judgment is to have the same faith and credit in Delaware as it does in Georgia, that requirement does not give the Georgia judgment extraterritorial effect upon assets in other states. So far as the assets in Georgia are concerned the Georgia judgment of probate is in rem; so far as it affects personalty beyond the state, it is in personam and can bind only the parties thereto or their privies." 48

Insofar as this case merely holds that a probate decree in rem is not entitled to full faith and credit in another state, as applied to property there, it follows a long line of predecessors in the same Court. As a judgment in rem, operating solely upon Georgia property, its effect, including the determination of Georgia domicile, could not be disputed either in Georgia or another state. But because the New York administrator would have no standing in Georgia to contest the will or the determination of domicile, it does not follow that he could not raise those questions in another state as they relate to property there which was not subject to the Georgia jurisdiction in rem. The clear inference from this opinion is that he would be so precluded only if he were before the Georgia court, or so represented there, as to be bound by the Georgia judgment in personam as well as in rem. Was the New York administrator, who was not a party in Georgia, so represented as to be bound in personam? Does the answer to this question depend upon Georgia doctrines of res judicata and the

48. Riley v. New York Trust Co., 315 U. S. 343, 353 (1942). 
Georgia conception of the representative or class suit? If, under Georgia law, the administrator is bound in personam, does the full faith and credit clause require a like result in other states? Or, if Georgia professes to bind the administrator in personam by representation of the husband, does she violate due process of law? These were the important issues "preriously undecided by this Court."

On one point all members of the Court were agreed. Since the New York administrator was charged with the duty of paying inheritance taxes upon the estate, his interest was adverse to that of the husband and next of kin, who were before the Georgia court; and if the effect of the probate decree in Georgia in personam was to bind him by representation of those so in adverse interest, it would be a denial of procedural due process. In his concurring opinion Chief Justice Stone relied upon that ground alone and found it unnecessary to consider the other questions discussed by Mr. Justice Reed. Mr. Justice Frankfurter and Mr. Justice Jackson concurred with the Chief Justice. In the main opinion, however, Mr. Justice Reed considered the Georgia law on representation as disclosed in the record and concluded that thereunder the Georgia judgment could bind the New York administrator only in rem. This conclusion relegates to the status of a dictum the further very interesting observation that "By the Constitutional prorision for full faith and credit, the local doctrines of res judicata, speaking generally, become a part of national jurisprudence, and therefore federal questions cognizable here." 40 If this dictum can be relied upon, it would seem that, within the linits of procedural due process, state doctrines or res judicata in personam may be enforced in other states under the full faith and credit clause. In other words, where under its own local law an F-1 probate judgment operates both in personam and in rem and binds in personam the parties, their privies, and others participating in the litigation or represented therein, the judgment may be entitled to constitutional full faith and credit in F-2 as a judgment in personam as to persons so bound in F-1. If, however, the F-1 judgment professes to bind in personam by representation a person who was not a formal party to the suit, the state doctrine of representation must comply with the Supreme Court test of procedural due process, or the judgment will be invalid in F-1 as well as in F-2 as to one so represented. The Supreme Court test of due process for state doctrines of representation in class suits was announced in 1940 in Hansberry v. Lee. ${ }^{50}$

49. Id. at 349 .

50. 311 U. S. 32 (1940). The author does not contend that all judgments in personam which are valid under the test of due process are entitlcd to full faith and credit elsewhere under present decisions of the Court. The speculation to that effect is merely an attempt to project the trend of recent decisions. In the past the Court has held that a judgment may be res judicata in personam in the state where rendered and yet nut be entitled to full faith and credit in another state. In Bigelow v. Old Dominion Copper 
The Court required that members of the class who participate in the litigation adequately represent the absent party in such a way as to insure protection of his interests. If their interests are adverse to his, the judgment is not res judicata as to him.

The only question necessarily determined by the Supreme Court in the Riley case was that Delaware had not denied full faith and credit to the Georgia judgment when Delaware made a determination of New York domicile and turned local property over to the New York representative. If, however, the analysis is correct as to the difference in impact of the principles of res judicata in personam and in rem, there are further interesting implications with respect to the effect of the full faith and credit clause upon two different controversies which lay behind the whole litigation. The first was whether the husband was entitled to an indefeasible share in the wife's property, which was assured him under New York law, but not under Georgia law. The second was which state, New York or Georgia, was entitled under its own laws to levy an inheritance tax. Both controversies would depend upon the domicile at death. As to the husband's rights, it would seem that the Georgia decision was conclusive as to property everywhere, since he and the other claimants to the estate were before the Georgia court in personam. As to the right to tax, however, the New York representative and the State of New York, not having been parties to the Georgia proceeding, would be bound by the Georgia determination of domicile only as to property in Georgia. The restlt is that the decedent was domiciled in different places for different purposes: in Georgia, for the purpose of determining the husband's rights in her estate wherever situated; in New York, for the purpose of determining the right to tax the property before the Delaware court.

Mining and Smelting Co., 225 U. S. 111 (1912), the Court held that F-2 might inguire whether, under F-2 law or "general law," F-1 had jurisdiction over the person of one not a formal party in F-1, even though under F-1 law the judgment was res judicata as to him. That holding long preceded the decisions, discussed above, in which the Court expanded its application of the res judicata principle and curtailed the dogma that in F-2 the jurisdiction of F-1 is always open to inquiry. Another recent illustration of the narrowing zone of freedom of state action between the due process and the full faith and credit clauses may be found in Williams v. North Carolina, 317 U. S. 287 (1942), holding that a default divorce decree obtained in the state of plaintiff's residence on service by publication is entitled to full faith and credit in another state. In addition to attaclss on the ground of lack of F-1 jurisdiction, there were in the past a number of other judticially sanctioned reasons for refusing to recognize or enforce a forcign judgment which was valid in the state where rendered. It was held, for example, that F-2 might refuso recognition where the F-1 judgment was against the public policy of F-2 or where it involved enforcement of F-1 penal or fiscal laws. Even here the Supreme Court is tending to say that these defenses are no longer available. Milwaukee County v. White Co., 296 U. S. 268 (1935) (penal and fiscal laws); Fauntleroy v. Lum, 210 U. S. 230 (1908) (public policy). 
A recent decision in the Fifth Circuit Court of Appeals ${ }^{\text {t1 }}$ recognizes also the distinction between the effects of a probate decree operating both in rem and in personam. Although no reliance was placed upon the full faith and credit clause, the court did apply the recently enlarged Supreme Court conception of res judicata in a probate case involving disputed domicile. The testator left two wills entirely irreconcilable in terms. The earlier will was probated in Massachusetts in a proceeding which purported to be domiciliary and in which Florida claimants were cited only by publication. The later will was probated in Florida, and it was found that testator was domiciled in that state. The beneficiary of the Massachusetts will appeared in the Florida case and sought revocation of probate on grounds of lack of testamentary capacity and undue influence in obtaining the second will, and clained the estate under terms of the earlier will. Before this contest was disposed of, the Florida representative brought action in the federal court in Florida to collect insurance assets of the estate. The insurer procured an interpleader of the Massachusetts claimant and was discharged upon paying the money into court. The interpleader proceeding was then stayed, pending the disposition of the contest in the Florida probate court. When the second will was there upheld, the federal court ordered the money paid to the Florida representative. In affirming this decision, the Circuit Court of Appeals relied upon the res judicata principles recently established in the Supreme Court and remarked that "As against the parties actually contesting it, a court may conclusively adjudicate its own jurisdiction." ${ }_{2}$ The relevancy of this remark rests on the assumption that domicile was a jurisdictional fact which each state could properly determine for itself, and that, except for the res judicata effect in personam of the Florida judgment, the federal court could have made an independent determination of domicile in order to determine which was the true domiciliary representative to whom the insurance was payable.

\section{Discretion as to Recognition of Foreign Decrees}

Returning to cases uncomplicated by an in personam application of the res judicata principle, the question arises as to existing criteria for determining the extraterritorial recognition of probate decrees of the type referred to herein as ex parte. Certain New York decisions have asserted that such recognition is in the discretion of the New York surrogate. ${ }^{53}$

51. Roberts v. Bathurst, 112 F. (2d) 543 (C. C. A. 5th, 1940).

52. Id. at 545 .

53. See In re Cornell's Will, 267 N. Y. 456, 196 N. E. 396, 101 A. L. R. 1502, 1510 (1935), holding that the surrogate in his discretion could decline to try the issue of domicile between two foreign representatives each claiming to have been appointed at the dumicile of decedent, but could turn over New York assets to one of them for litigation elsewhere. See also In re Beban's Estate, 135 Misc. 25, 237 N. Y. Supp. 701 (Surr. Ct. 1929); 
There are undoubtedly many judicial controversies in which the interests of justice are best served by leaving the solution to the sound judgment of a judge rather than by prescribing a fixed rule, but the writer believes that the recognition of foreign probate decrees is not such a problem. The lawyer handling an estate situated in several states is confronted, at best, with a number of uncertainties which interfere with the ideal of unitary administration and add to the expense of his total task. In the typical case he probates a will or opens an administration proceeding at the last domicile of the decedent, and rightfully assumes, on the basis of precedent, that for many purposes the courts in other states will look upon that as the primary administration. Having established the fact of testacy or of intestacy in that state, the handling of property elsewhere will be greatly facilitated through definite rules in the other states as to the effect of the domiciliary decree, particularly if such rules favor recognition on issues of essential validity. If the desirable end of a single effectual probate is to be achieved, it seems clear on the basis of both precedent and policy that it must come through a more general recognition of the conclusiveness of a domiciliary probate. Yet if such recognition is left to the discretion of each probate judge, there is little probability that general recognition will be achieved, for the judge will be reluctant to preclude a contest insisted upon by local claimants who have not seen fit to journey to the state of decedent's domicile to litigate their claims in the first instance. Furthermore, the domiciliary representative or those claiming under the domiciliary decree may spend much time and money attempting to induce judges in other states to accept the domiciliary adjudication as conclusive.

A good illustration of the latter possibility is to be found in litigation concerning the estate of Elizabeth Eaton. ${ }^{54}$ It may not be more than a coincidence that this litigation took place in New York, where recognition of foreign domiciliary decrees is sometimes said to be discretionary. The testatrix died in 1906, domiciled in Michigan, leaving most of her estate in the form of securities in custody of a relative in New York. A will was admitted to probate in Michigan, but a proffered codicil was rejected on the ground of want of testamentary capacity. Both will and codicil were probated in New York. Thereafter, during the next quarter of a century the Michigan representative and the claimant under the Michigan decree

In re Harriman's Estate, 124 Misc. 320, 208 N. Y. Supp. 672 (Surr. Ct. 1924), aff'd veithout opinion, 216 N. Y. Supp. 842 (App. Div., 1st Dep't 1926). Cf. In re Marsland's Estate, 142 Misc. 230, 254 N. Y. Supp. 293 (Surr. Ct. 1931), in which it was said that the admission to probate by a Swiss court of the will of a Swiss clomiciliary "conclusively $\mathrm{dem}$ onstrates" the validity of the document according to Swiss law, and that under the Uniform Wills Act, Foreign Executed, adopted by New York Laws 1919, c. 294, such a will, if in writing and subscribed by the testator, is valid for all purposes in New York.

54. For a summary of this extended litigation, see Watkins v. Madison County Trust \& Deposit Co., 40 F. (2d) 91 (N. D. N. Y. 1930); an earlier case in the procecdings, Higgins v. Eaton, 202 Fed. 75 (C. C. A. 2d, 1913). 
endeavored unsuccessfully through eight distinct proceedings in the New York state and federal courts to procure recognition of the domiciliary decree and distribution of the New York property in accordance with it.

In states other than New York, the matter of recognition is usually handled by fixed conflict of laws rules, rather than by the discretion of the probate judge. But such rules are not uniform and in some states are much in need of clarification; and different rules frequently exist in the same state depending upon whether the property in $F-2$ is real or personal.

\section{The Distinction Between Real and Personal Property}

The formulation of existing rules concerning recognition of foreign probate decrees is complicated by the fact that most states have some type of legislation relating to the probate of foreign wills. This legislation varies in terms from state to state, and it is frequently difficult, moreover, to determine the extent to which a particular case turns upon such legislation. By putting aside for later consideration the relevant statutes and cases in which they seem to have been of considerable importance, we arrive at what may be termed common law rules on the extraterritorial recognition of probate decrees. In deriving those rules from the cases, it becomes necessary to distinguish between personal property and real property subject to $F-2$ jurisdiction.

As to personal property subject to $F-2$, the majority rule is reflected in the Restatement of Conflict of Laws, which provides that:

"A judgment in administration proceedings by a competent court in the state of domicil will be followed by the courts in other states in so far as the judgment relates to movables." $5 \pi$

The Restatement contains no analogous rule covering real property, but a comment upon the above section explains that the action of a court in a state other than the situs concerning succession to land has no extraterritorial effect. ${ }^{56}$

55. Restatenient. Cosflict of Laws (1934) $\$ 470(1)$. In a comment on this subsection the rationale is stated as follows: "The statement in this Subsection is based upon the principle that, unless provided otherwise by statute, the devolution of movables in both testate and intestate succession is determined by the law of the state of domicil of the decedent at the time of death. . . . An adjudication by a court at the domicil, therefore, with regard to a particular person's estate, will be conclusively received in other states as the application of the domiciliary law as applied to that estate. This rule is applicable although the persons participating in the litigation and the property being administered are different from those involved in the proceedings in the domiciliary state." The precise terms "movables" and "immovables" rather than "realty" and "personalty" are used in the Restatement and frequently in critical writings on conflicts of laws, but the courts usually use the terms "personal property" and "real property" and the usage of the courts is followed here.

56. Restatearent, Conflict of Laws (1934) $\$ 470(1)$, comment $c$. The reason assigned is that "Succession to land is governed by" the law of the state where the land 
The decisions supporting the above formulation as to personal property are somewhat unsatisfactory in that many of them, as has been heretofore pointed out, place a spurious reliance upon the full faith and credit clatse of the Federal Constitution. Some of the best opinions upon the subject, when examined, prove to be dicta rather than holdings. Furthermore, the opinions frequently assume that recognition of the domiciliary decree follows automatically from the common law choice of law rule under which the succession to personal property, testate or intestate, is governed by the law of the domicile. ${ }^{57}$ This practice of making interdependent the problems of choice of law and recognition of foreign judgments, reflected also in the Restatement, ${ }^{58}$ should not be too lightly dismissed. It has resulted in much confusion in thought. The two problems, although related to a limited extent, present important differences in policy. The maxim mobilia sequnutur personam as a choice of law rule involves no more than the recognition that it seems fair to distribute a decedent's property, testatc or intestate, according to the substantive rules prevailing at his domicile without regard to the location of the property or the court in which distribution is made. It may be supposed that he was familiar with those rules, or that he and his legal adviser had them in mind in considering the

is." Thus, as to both real and personal property, the effect of foreign prohate judgments is made dependent in the Restatement upon the common law choice of law rules. Sec note 55 sitpra.

57. See Goodman v. Winter, 64 Ala. 410 (1879); Brock's Adm'r v. Frank, 51 Ala. 85 (1874). But see Marx v. Loeb, 228 Ala. 196, 153 So. 266 (1934) (foreign probated will and rights thereunder cannot be recognized until probated locally); Knight $v$. Whecdon, 104 Ga. 309, 30 S. E. 794 (1898); Duckwall v. Lease, 20 N. E. (2d) 2104 (Ind. App. Ct. 1939) ; Kurtz v. Kurtz's Estate, 169 Md. 554, 182 At1. 456 (1936) (full faith and credit clause relied upon); Morrison v. Hass, 229 Mass. 514, 118 N. E. 893 (1918) (follows the theory of Crippen v. Dexter, pages 229-31 supra) ; In re Coppock's Estate, 72 Mont. 431, 234 Pac. 258 (1925) [follows State ex rel. Ruef v. District Court, 34 Mont. 96, 85 Pac. 866 (1906)] ; Nelson v. Potter, 50 N. J. L. 324, 15 Atl. 375 (188S); McEwan v. Brown, 176 N. C. 249,97 S. E. 20 (1918) (both real and personal property in $\mathrm{F}-2$ and domiciliary probated will held subject to challenge for undue influence and lack of testamentary capacity as to real property, but conclusive as to personal property) ; Grignon v. Shope, 100 Ore. 611, 197 Pac. 317 (1921) (full faith and credit) ; Cornell v. Burr, 32 S. D. 1, $141 \mathrm{~N}$. W. 1081 (1913) ; Hodge v. Taylor, 87 S. W. (2d) 533 (Tex. Civ. App. 1935) [follows Holland v. Jackson, 121 Tex. 1, 37 S. W. (2d) 726 (1931), in reliance upon full faith and credit clause]. Compare Martin v. Stovall, 103 Tenn. 1, 52 S. W. 296, 48 L. R. A. 130 (1899), with Woodfin v. Union Planters Nat. Bank \& Trust Co., 174 Ten11. 367, 125 S. W. (2d) 487 (1939). Where the foreign decree has been non-domiciliary, it has ustrally been denied recognition. See In re Clark's Estate, 148 Cal. 108, 82 Pac. 760 (1905); In ra Griggs' Estate, 135 Minn. 353, 160 N. W. 1018 (1917); In rc Cameron's Estate, 47 App. Div. 120, 62 N. Y. Supp. 187 (3d Dep't 1900), aff'd zeithout opinion, 166 N. Y. 610, 59 N. E. 1120 (1901) ; In re Gaines' Will, 84 Hun 520, 32 N. Y. Supp. 398 (Sup. Ct. 1895), aff'd, 154 N. Y. 747, 49 N. E. 1097 (1897) ; De Tray v. Hardgrove, 52 S. W. (2d) 239 (Tex. Comm. App. 1932); Vogel v. New York Life Ins. Co., 55 F. (2d) 205 (C. C. A. 5th, 1932).

58. See notes $\mathbf{5 5}$ and 56 supra. 
disposition of his property. When, however, the maxim is to be extended in application so that an ex parte adjudication by the court of the domicile will be conclusively received elsewhere as an application of the domiciliary: law, it must be on the assumption that it is fair to require all beneficiaries who claim an interest in the estate, wherever they may be, to appear at the domicile for purposes of litigation. It is suggested that such an assumption should be made, not alone by implication from the clooice of law rule, but because it offers the only practical possibility of procuring a unified administration and avoiding the confusion, expense, and delay incident to conflicting adjudications in the various states where property is situated. The doctrinal difficulties involved in carrying out this assumption are indicated by a minority group of decisions which adhere to the power theory' even as to personal property. ${ }^{59}$ The rationale of those decisions is that, since a probate proceeding is an exercise of jurisdiction in rem, the F-1 judgment is effective only as to property within the state. This technical obstruction to a unified administration, however, may be obviated, as has been suggested above, ${ }^{60}$ by treating the subject matter of the proceeding as the status of testacy or intestacy rather than as the property situated in the state. Extraterritorial recognition of the $F-1$ decree is then achieved by application of the F-2 conflict of laws rule that the decedent's last domicile is the appropriate forum for a final determination of that status.

In contrast to the extraterritorial recognition usually given to a domiciliary decree where personal property in $\mathrm{F}-2$ is concerned, the great weight of authority denies such recognition as to real property. ${ }^{01}$ The inconveni-

59. Higgins v. Eaton, 202 Fed. 75 (C. C. A. 2d, 1913) : New York Trust Co. v. Riley. 16 A. (2d) 772 (Del. 1940); In re Gifford's Will, 279 N. Y. 470,18 N. E. (2d) 663 (1939); Olney v. Angell, 5 R. I. 198 (1858); Bowen v. Johnson, 5 R. I. 112 (1858). Where the property in controversy in F-2 was within the territorial limits of F-1 when the F-1 judgment was entered, the F-1 judgment will be respected even though F-2 is the domicile. See State v. Wright, 194 Ark. 652, 109 S. W. (2d) 123 (1937); Neweomb v. Neweomb, 108 Ky. 582, 57 S. W. (2d) (1900); Walton v. Hall's Estate, 66 Vt. 455, 29 A11. 803 (1894).

60. See note 9 stpra.

61. Clarke v. Clarke, 178 U. S. 186 (1900); Foster v. Kragh, 107 Colo. 389, 113 P. (2d) 666 (1941) ; Ferriday v. Grosvenor, 86 Conn. 698, 86 Atl. 569 (1913) ; Pritchard v. Henderson, 2 Penn. 553, 47 Atl. 376 (Del. 1900); Trotter v. Van Pelt, 144 Fla. 517, 198 So. 215, 131 A. L. R. 1018, 1023 (1940); Chidsey x. Brookes, 130 Ga. 218, 60 S. E. 529 (1908); McNamara v. McNamara, 293 Ill. 54, 127 N. E. 130 (1920) (construction of will); Dibble v. Winter, 247 Ill. 243, 93 N. E. 145 (1910); Evansville Ice \& Cold Storage Co. v. Winsor, 148 Ind. 682, 48 N. E. 592 (1897); Foster v. Jordan, $130 \mathrm{ky}$. 445, 113 S. W. 490 (1908) ; Sneed v. Ewing, 5 J. J. Mar. 460 (Ky. 1831) ; Woodville v. Pizzati, 119 Míss. 442, S1 So. 127 (1919); Keith v. Johnson, 97 Mo. 223, 10 S. W. 597 (1889) ; Allaire v. Allaire, 37 N. J. L. 312 (1875), aff'd, 39 N. J. L. 113 (1876) ; Lowe v. Plainfield Trust Co., 216 App. Div. 72, 215 N. Y. Supp. 50 (1st Dep't 1920) ; MreEwan v. Brown, 176 N. C. 249,97 S. E. 20 (1918); Buwen v. Jolunson, 5 R. I. 112 (1858); Cornell v. Burr, 32 S. D. 1, 141 N. W. 1081 (1913); Kirkland v. Callown, 147 Tenn. 38s, 248 S. W. 302 (1923). Contra, Brock's Adm'r v. Frank, 51 Ala. $\$ 5$ (1874); Crippen v. 
ence of multiple litigation incident to this distinction between real and personal property may be illustrated by a North Carolina case. ${ }^{62}$ The testator died domiciled in Virginia leaving all of his property by will to his cousin, the defendant, who was also named executor. The will was probated in Virginia and then filed in North Carolina, where the testator owned both real and personal property. The heirs at law divided the North Carolina property and then sued the defendant as executor and devisee claiming that the will was invalid for lack of testamentary capacity, that it was procured by undue influence, that it was deficient in form under North Carolina law, and that it constituted a cloud on the plaintiff's title. It was held that a contest was open upon all those grounds as to the real estate, but that a demurrer should be sustained as to personal property, in regard to which plaintiffs if so advised, shauld proceed by caveat in Virginia.

It seems clear that if the convenience of a unified administration is to be attained through wider extraterritorial recognition of domiciliary probate decrees, such recognition must be extended as to both real and personal property. How convincing are the reasons given by the cases which deny recognition as to land?

Many of the decisions rely upon the common law choice of law rule under which the validity of a devise depends upon the law of the situs of the land. That rule, as will more fully appear hereafter, has proven to be too restrictive and has been modified in many states by legislation establishing alternative reference points for choice of law, so that wills of both real and personal property are valid if executed in the manner prescribed by the law of the place where executed, or of the testator's domicile, or in accordance with local law. Where such legislation has been adopted, the most common reason given for the distinction between real and personal property no longer exists. In either case a foreign domiciliary decree admitting a will to probate may be regarded by the court of the situs as an authoritative finding that the domiciliary standards of validity have been complied with, and those standards are made applicable to local property under the local conflict of laws statutory rules. But, as has been heretofore pointed out, there is no essential connection or complete correlation between choice of law rules and the determination of effect of foreign judgments. The above statutes refer primarily to standards of formal validity; and where they have not been adopted, there can be no doubt that a foreign will, although probated at the domicile, must comply with the local Wills Act in order to be effective as to local real estate. But while the question of formal validity may be open under the local Wills Act,

Dexter, 79 Mass. 330 (1859) ; State $c x$ rel. Ruef v. District Court, 34 Mont. 96, 85 Pac. S66 (1906); Holland v. Jackson, 121 Tex. 1, 37 S. W. (2d) 726 (1931).

62. McEwan v. Brown, 176 N. C. 249,97 S. E. 20 (1918). 
because in no way an issue in the litigation at the domicile, it does not necessarily follow that contest should be allowed on matters of essential validity, such as testamentary capacity and undue influence, where the will has been admitted at the domicile. In other words, quite apart from the questions as to standards of formal validity, it would seem desirable in the interests of unified administration to adopt a conflict of laws rule recognizing that the court of domicile is primarily the appropriate forum in which to raise questions of essential validity of a will; and if the will has been there adjudged either valid or invalid, the decree should be recognized as conclusive on those grounds elsewhere both as to real and personal property. If the conflict of laws rule of the situs provides for validity of a will executed in accordance with the standards of formal validity prevailing at the domicile, then a foreign domiciliary decree admitting the will should be equally conclusive as to form.

Decisions denying recognition as to land are almost unanimous in adherence to the power theory argument that land is subject exclusively to the jurisdiction of the courts of the situs and that recognition of a foreign decree would constitute an abandonment of that jurisdiction. Recognition of the foreign decree, however, does not involve a surrender of jurisdiction or power over local land. It merely means that in the exercise of that power the court of the situs adopts a conflict of laws rule which it believes takes adequately into account the foreign element in the case, namely, the fact that the will has been either rejected or established at the domicile, and declares that under those circumstances the law of the forum precludes a local contest on essential validity of the will. The court of the situs merely decides to act in a truly ancillary manner in furtherance of the primary administration. The foreign decree does not adjudicate the title to local land. Only the court of the situs can do that, but in doing so it may prescribe its own conditions for the recognition of the foreign decree. Or, as Professor Nussbaum says, it tests "in the forum's own terms, a requirement for granting territorial expansion to the res judicata effect of the foreign judgment." 03 The foreign judgment receives its extraterritorial recommendation as res judicata because the doctrine is applied under the common law or statutory conflict of laws rule in $\mathrm{F}-2$, although not yet, perhaps, required by the full faith and credit clause of the Constitution.

Closely associated with the argument in terms of jurisdiction is the policy argument that land titles should not be subjected to the uncertainty incident to recognition of a foreign judgment. This ubjection disappears. however, once it is understood that the forum may establish its own conditions for recognition. Most states make statutory provision for the recording of foreign probate decrees, or for ancillary probate of foreign

63. See Nussbaum, supra note 5 , at 225 . 
wills affecting local property, and compliance with such provisions as a condition to recognition would adequately safeguard the objectives of the land recording system. Even Massachusetts, long an exponent of the rule of recognition, has required local ancillary probate of a foreign will admitted at the domicile, as a condition precedent to recognition of rights in local land under such will. ${ }^{64}$ With the provision of such safeguards, there would seem to be little reason to require the continuance of the distinction between real and personal property. If it is fair, in the interests of a unified administration, to require all prospective contestants of a will to appear and make their attack at the testator's domicile, where personal property is situated outside the domiciliary state, it seems equally reasonable to impose such a burden upon the claimants under a will of land.

\section{EFFeCt of Legislation}

Legislation in some states has played an appreciable part in determining the effect given judicially to foreign probate decrees. Frequently, however, the statutes are not clear and precise on the point, and the conclusiveness of the foreign decree depends upon the cumulative effect of a number of statutory provisions each bearing only indirectly upon the problem. The pattern of relevant legislation differs from state to state, and broad generalizations are hazardous. Furthermore, statutory provisions reasonably clear in their import are sometimes construed in subordination to broad principles of jurisdiction or full faith and credit along lines heretofore discussed. Complete analysis of the law of each state cannot be undertaken here. Only such generalizations will be attempted as seem relevant to an evaluation of existing statutes in terms of their effectiveness in contributing to a unified administration centered at the decedent's last domicile.

The relationship between the problems of choice of law and effect of foreign judgments has already been indicated at some length. That relationship requires that attention be given to legislation which, in the conflict of laws sense, fixes the standards of validity for a will. In a few states the statutes are in confirmation of the common law rules under which validity of wills of realty is determined by the law of the situs and wills of personalty by the law of the testator's domicile at the time of his death. ${ }^{05}$

64. Solis v. Williams, 205 Mass. 350, 91 N. E. 148 (1910) ; accord, Marx v. Loeb, 228 Ala. 196, 153 So. 266 (1934) ; Sayre v. Sage, 47 Colo. 559, 108 Pac. 160 (1910) ; Ferriday v. Grosvenor, 86 Conn. 698, 86 At1. 569 (1913); Chidsey v. Brookes, 130 Ga. 218, 60 S. E. 529 (1908) ; Howard v. Merker, 73 Ind. App. 400, 127 N. E. 807 (1920); Smith v. Reneau, 188 Okla. 629,112 P. (2d) 160 (1941); Olney v. Angell, 5 R. I. 198 (1858); Walton v. Hall's Estate, 66 Vt. 455, 29 Att. 803 (1894).

65. Cal. Prob. Code (Deering, 1941) §26; DeL. Rev. Code (1935) \$3714 (will of nonresident probated elsewhere, valid as to personal property, although not in compliance with Delaware law); FLA. Stats. Anv. (1941) § 731.07(3); GA. Code (1938) \$§ 102.108, 
Most of these statutes expressly provide for, or do not exclude, the validity of wills of personalty if executed in accordance with the local Wills Act even though not in accordance with the law of the domicile, thus providing alternative reference points as to personal property of a non-resident decedent.

In more than half the states, statutes have been enacted which modify the common law rules by providing alternative reference points for standards of formal validity of wills. These statutes are general in terms and make no distinction between real and personal property. They differ concerning the permissible reference points chosen. The largest group provides that a foreign executed will shall be deemed legally effective if executed in accordance with the local law of the adopting state or in the mode prescribed by the law either of the place where executed or of the testator's domicile. $^{66}$ It should be observed that the reference to the law of testator's domicile is indefinite as to the time of reference, in failing to specify either the time of execution or of death. Most of these statutes were adoptions of the old Uniform Wills Act, Foreign Executed, declared obsolete by the Conference of Commissioners on Uniform State Laws in

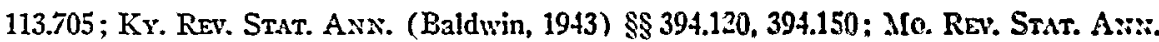
(1939) $\$ \$ 253,550 ;$ N. J. STAт. ANN. (1939) tit. 2, c. 31, $\$ 27$, tit. 3, c. 2, $\$ \$ 37-45 ;$ N. C. Code Axs. (Michie \& Sublett, 1939) §4152; PA. St.1т. (Purdon, 1936) tit. 20, § 231; VA. Code Axx. (Michie, Sublett \& Stedman, 1942) \$\$ 5231, 5251; IV. VA. Cona A:ה: (Míchie, Sublett \& Stedman, 1943) $\S \S 4043,4073$.

66. Alaska Consp. Laws (1933) $\$ 4625$ (provided foreign will is in writing and subscribed by testator); Iowa CoDE (Reichmann, 1939) $\$ 11893$ (provided foreign will is in writing and subscribed by testator); Kus. Gev. Stat. Aww. (Corricl, Supp. 1941) $\$ 59.609$ (provided foreign will is in writing and subscrihed by testator; priur to 1929 this section contained the wording of the Uniform Wills Act, Fureign Executed, but in that year it was amended to make more definite the time of reference to law of testatur's residence, i.e., "either at the time of its execution or of the testator's death") : LA. Ge:. Stat. Axx. (Dart, 1939) $\$ 972 \$$ (provided foreign will is in writing and subscrilsed to by testator); MD. Aws. Cone (Flack, 1939) art. 93, $\$ 350$ (provided foreign will is in writing and subscribed by testator); MAss. Axw. Laws (Mrichie, 1932) c. 191, $\$ 5$ (pruvided foreign will is in writing and subscribed by testator); Mrcr. ST.1T. As:. (Mraure. 1943) $\$ 27.3178(97)$ (provided foreign will is in writing and subseribed by testatur); Minn. Stats. (Mason, 1927) $\$ \$ 73 \$$ (if not executed accurding to Mlinnesuta law, will must be in writing, signed by the testator, and valid according to the laws of the state or country in which it was made or of the testator's domicile); Ner. Coss. Srat. (Kyle, Supp. 1941) $\$ 30.205$ (provided foreign will is in writing and subseribed by testator); NEv. Cosrp. Laws (Hillyer, 1929) $\$ 9929$ (provided foreign will is in writing and subscribed by testator); N. Y. Deccoent Estate LAw $\$ 223$ (provided fureign will is in writing and subscribed by testator); R. I. Gex. LAws A:zis. (1938) c. 565, \$35 (provided foreign will is in writing and subscrilied by testator); VT. Pta Laws (1933) $\$ 2767$ (provided foreign will is in writing and subseribed by testatur); WAsa. Rav. Stat. Ann. (Remington, 1932) \$1395; WIs. Stat. (1941) \$238.07 (provided forcign will is in writing and subscribed by testator, and provided further, this seetion shall nut affect such nuncupative wills as are mentioned in the chapter). 
1940, and superseded by section 7 of the Model Execution of Wills Act promulgated at that time. ${ }^{67}$ In several other states the permissible reference points are the local law, the law of the place of execution, or the law of testator's domicile at the time of execution. ${ }^{68}$ Other statutes provide but two reference points, the local law and the law of the place of exectution. ${ }^{60}$ In a few states the only relevant statutes found were those providing for ancillary probate or recording of wills, admitted to probate elsewhere, on authenticated copies of the foreign probate. In three of those states admittance to record or ancillary probate is authorized if, on hearing, it appears the will was executed according to the local law or the law of the place of execution or the law of the place where the testator was at the time domiciled. $^{70}$ The Ohio statute provides that authenticated copies of wills executed and proved according to the laws of any other state may be admitted and shall have the same validity as wills duly made in Ohio. ${ }^{71}$ The South Carolina statute authorizes admission, on authenticated record, of wills admitted in any other state, regardless of any provisions of law of South Carolina relating to the witnessing and attestation of wills. ${ }^{72}$

Several observations may be made concerning the relationship between these choice of law statutes and the question of recognition of foreign probate decrees with which we are directly concerned. It will be recalled that existence of legislation of this kind has been one of the factors which in a few cases led the courts to a broader outlook toward recog-

67. 9 U. L. A. (1942) 277. Section 7 of the Model Act is stubstantially like the Uniform Wills Act, Foreign Executed, but it is definite as to time of reference to the law of testator's domicile by providing for that law at the time of execution. Section 8 of the Model Act provides that the Act shall not apply to wills offered for ancillary probate in this state which have been admitted to probate in the state or country of the testator's domicile. The probable explanation for this exclusion is the existence of a Uniform Wills Act, Foreign Probated. The Model Execution of Wills Act was adopted, Tenn. Pub. Acts 1941, c. 125.

68. Ilx. Rev. Stat. (Bar Ass'n Ed., 1943) c. 3, §237 (provided foreign will is written and signed by testator); Mont. Rev. Code ANv. (Anderson \& MeFarland, 1935) \$6988; N. D. Comp. Laws Ann. (1913) §5653; OkLA. Stat. Ann. (1941) tit. \$4, \$\$71, 72; S. D. CoDE (1939) $\$ 56.0212$ (provided will is in writing and subscribed by testator); Tenn. Pub. Acts 1941, c. 125, $\S 7$ [provided foreign will is in writing; this is an adoption of the Model Execution of Wills Act, 9 U. L. A. 277 (1942) ]; UTAu CODE ANs. (1943) \$101.1.14.

69. Ark. Dig. Stat. (Pope, 1937) §14557; Conn. Gen. Stat. (1930) §4876; Me. Rev. Stat. (1930) c. 76, §13; N. H. Rev. Laws (1942) c. 350, § 5; N. M. Stat. ANv. (1941) § 32.110; ORE. CoMr. Laws ANs. (1940) $\$ 18.701$ (alternative reference, law of place of execution only as to personal property; will of real property must comply with Oregon law).

70. Ariz. Code Ann. (1939) §38.215; Idaho Code Anv. (1932) §15.222; WYo. Rev. Stat. AnN. (Courtright, 1931) §88.303.

71. OHio GEN. Code (Page, 1938) §10511.5.

72. S. C. CODE (1942) $\S 8948$. 
nition. ${ }^{73}$ Where these statutes adopt as one of the alternative reference points the law of the testator's domicile, one of the most common reasons found in the cases for the distinction between real and personal property ceases to have validity. The preservation of that distinction in the Restatement, as was pointed out above, was rationalized in the commentary, upon the basis of the common law choice of law rules. ${ }^{74}$ It would seem that if a foreign domiciliary decree is to be received as conclusive in application to personal property because it indicates that the domiciliary standards of execution have been met, it should be equally conclusive as to land where, under statutes, the domiciliary standards have been adopted as an alternative reference point for both kinds of property.

It seems obvious that most of these statutes were drafted without taking into consideration the one legitimate connection between choice of law and the problem of recognition of foreign probate decrees. As has been indicated heretofore, that one legitimate connection is found in the fact that if the foreign domiciliary decree is to be taken as conclusive on formal validity of the will, the standards for formal validity at the domicile and the situs should be the same. If they are not the same, the judgment at the domicile would in no way touch the issue of whether the will complies with the standards at the situs. The statutes, however, frequently adopt as a reference point the law of the place of execution to the exclusion of the law of the testator's last domicile. There can be no objection to adopting the law of the place of execution. The basic purpose of the statutes, no doubt, is to prevent failure of testamentary dispositions due to the slight variations in the standards of execution found from state to state. A wide array of alternative reference points would contribute to that objective. In view of the traditional importance attached to the law of the testator's last domicile in wills and administration cases, it would seem that among those reference points should be included the law of testator's domicile at the time of death. If that is done, the decree admitting the will in the primary administration may be accepted as putting at rest any issue of formal validity in a state whose conflict of laws rule adopts the domiciliary standards. It must frequently happen, of course, that the place of execution and the domicile at death will be the same. But, in order to provide for the case where they are not the same, these statutes should include as one permissible reference point the law of the last domicile. The old Uniform Wills Act, Foreign Executed, was conveniently vague, in its reference to the law of testator's domicile, in not specifying the time of the reference. As carried into section 7 of the new Model Act, the reference is clear as to time, but less satisfactory, in that it refers to the time of execution. ${ }^{75}$

73. See discussion of Crippen 2. Dexter, pages 229-31 supra and State ex rel. Rtsef $2:$ District Court, pages 235-36 supra.

74. See notes 55 and 56 supra.

75. See note 67 supra. 
The change in the old Uniform Act made by the Kansas legislature seems preferable in providing for reference to the law of the domicile "either at the time of its execution or of the testator's death." 70

One final observation concerning choice of law statutes and recognition of foreign decrees should be made. Should recognition be extended to the decrees of all states whose law is adopted as an alternative reference point under these statutes, or should it be confined to foreign domiciliary decrees? It is suggested that only a domiciliary probate decree should be accepted as conclusively establishing the will on all grounds, or as conclusively finding it invalid for lack of testamentary capacity or because of undue influence, fraud, or forgery. If the only issue involved were formal validity of the will under foreign law, a decree of any foreign court applying its own law and admitting the will might be accepted as conclusive in a state whose conflict of laws rule adopts the foreign standard of execution. But a decree rejecting the will for noncompliance with that standard would be conclusive only as to that particular reference point, and the will might still be valid under the local law or under the law of some other state whose standards are adopted as a reference point under the local statute. It should also be observed that F-1 may itself have alternative reference points in its conflict of laws rule. Where F-1 is the domicile, it would contribute to the conclusiveness of the domiciliary probate when questioned in F-2 if the conflict of laws rule in F-2 were to include among its reference points any alternative reference point to which the domiciliary law might refer. On issues of essential validity, however, the situation is different. The legal standards are substantially alike throughout the nation, and the issues are typically issues of fact. It is the purpose of this study to explore the possibility of establishing a single appropriate forum for final determination of those issues. Our practice and our legal history point to the deceased's domicile as that forum. As Professor Page has observed: "If one effectual probate is to be secured, the only probate which has any chance for general recognition under our law is the probate at testator's domicile." 77

Another type of legislation which frequently has an important bearing upon the problem under consideration is legislation providing for the ancillary probate or recording of wills upon authenticated copies of the will and the record of its admission to probate in another state. Every state has legislation of this kind, but the provisions are extremely varied from state to state. The basic purpose of all of the statutes seems to be to provide an alternative method of proof where the original will cannot be withdrawn from the files of the foreign court. Most of the statutes, however, contain some provision which declares the effect of admission to an-

76. Kan. Gen. Stat. ANn. (Corrick, Supp. 1941) §59.609.

77. 2 PAGE, op. cit. supra note 2, at 398. 
cillary probate or to record, or which leaves an inference of such effect because of the procedure provided for admission. For present purposes the statutes can best be classified and discussed with reference to those two types of provision: those expressly declaring the effect of admission to ancillary probate or record, and those which provide either for summary admittance or for notice and plenary hearing in such a way as to suggest that the foreign decree is or is not conclusive.

In a few states the statutes contain no express provision concerning the effect of admittance to local probate or record, but do provide for summary admittance upon certified record of foreign probate. ${ }^{78}$ Standing alone, these statutes by failing to provide for notice and hearing upon ancillary probate do not warrant an inference of legislative intent that the foreign probate be conclusive, since contest through careat filed after probate is commonplace in our law, and procedure on ancillary probate usually follows, in the main, the procedure of original probate. In one of the states, in fact, the supreme court construed the statute as relating merely to proof of a foreign will and said that it had no relevancy to the right to contest. ${ }^{79}$ In other states, however, there are related provisions which lend color to an inference that the local summary probate should be taken as conclusive, ${ }^{80}$ thereby leaving no effective opportunity to contest the validity of the will in the ancillary proceeding. For purposes of the present discussion, about the best that can be said for this group of inconclusive statutes is that they would not have to be amended if another statute were passed providing for conclusive effect of the probate from a sister state.

In another group of states, the statutes providing for ancillary probate contain no express provision for notice and hearing, but provide that upon admittance the will shall have the "same force and effect" as if originally proved and allowed in this state. ${ }^{81}$ These statutes can be conveniently con-

78. Ala. Cone ANN. (1940) tit. 61, $\$ 46$ (but if admitted outside the United States or some territory subject to the jurisdiction of the United States, it must be probated as in original proceedings, and may be contested in the same manner); Colo. STit. ANv. (Supp. 1942) c. 176, §62a; MoNt. Rer: Cones Axx. (Anderson \& McFrarland, 1935) $\$ \$ 10040,10041$; S. C. CoDE (1942) $\$ \$ 8948-8950$.

79. Foster v. Kragh, 107 Colo. 389, 113 P. (2d) 666 (1941).

80. See, e.g., AlA. Code ANN. (1940) tit. 61, §46; S. C. Code (1942) §8936. The latter provides that probate from a foreign country shall not be conclusive as to sanity of testator or fraud or imposition practiced in obtaining the will, unless it is proved in solemn form. This leaves open the inference that probate from another state of the United States, admitted under sections 8948 to 8950 inclusive, is not subject to contest.

81. DEr. REv. CODE (1935) §3711 (relates only to a foreign record of probate at the domicile; section 3712 provides that when recorded in the county where property is, it shall be "sufficient evidence") Ind. Stat. Axs. (Burns, 1933) \$7.t17; Kas: GEx. Stat. Ann. (Corrick, Supp. 1941) $\$ \$ 59.801,59.802$; ML. Asn. Code (Flack, 1939) art. 93, §369; N. J. Stat. Ans. (1939) tit. 3, c. 2, §40; N. Af. Strit. Axz:. (1941) §33.201; Onio GeN. Code (Page, 1938) §10511.5; VA. Cone Axrr. (Michic, Sublett \& Stedman, 1942) $\$ 5251$. 
sidered together with another and larger group which contain the same provision concerning the effect of local admittance, but differ in that they do make express provision for notice and hearing prior to ancillary probate. ${ }^{82}$ Included within this larger group are the few states which have adopted the Uniform Wills Act, Foreign Probated..$^{83}$ All of these statutes have a common weakness when examined for their usefulness in contributing to a final domiciliary probate which will be accepted as conclusive in an ancillary administration. If the will, on ancillary admittance, is to have the "same force and effect" as if originally proved and allowed local$1 \mathrm{y}$, it becomes necessary to inquire as to the conclusiveness of a local original probate. In many of the states in question contest through some form of proceeding is permissible for a specified time after an original probate. If an ancillary probate is to be treated as truly ancillary, there would seem to be no objection in such a state to giving it a greater degree of conclusiveness than would be proper for probate upon an original proceeding. In other words, the finality of the ancillary decree should be determined not by reference to the local law relating to an original probate, but by reference to the foreign primary decree upon which it is based. So long as the primary decree remains in full force and effect, contest should not be permitted in the ancillary proceeding. When it is shown in the ancillary proceeding that the primary decree has been reversed or vacated, the an. cillary decree likewise should be set aside.

Another weakness and uncertainty is found in all of these statutes which provide for notice and hearing before admission upon authenticated copies of foreign probate. They do not specify what issues may be presented in opposition at the hearing. In states where it is permissible to contest a will on grounds of essential validity before admission when it is offered for original probate, it is likely, unfortunately, that similar issues will be con-

82. Cal. Prob. Code (Deering, 1941) $\$ \S 360-62$; Conn. Gen. Stat. (1930) $\S 4889$; Idaho Code Ann. (1932) $\$ \S 15.220-15.222$; LA. Gen. Stat. Ann. (Dart., 1939) $\$ \$ 9729-$ 32; Me. Rev. Stat. (1930) c. 76, §14; Mass. Ann. Laws (Michie, 1932) c. 192, \$§9, 10; Neb. Comp. Stat. (Kyle, Supp. 1941) \$30.225; Nev. Comp. Laws (Supp. 1941) $\S 9882.32$; N. H. Rev. Laws (1942) c. $351, \S 13$; N. D. Conp. Laws AnN. (1913) $\$ 8672$; OkLa. Stat. ANn. (1938) tit. 58, $\$ \$ 11-53$; R. I. Gen. Laws Ann. (1938) c. 572, $\$ \S 10-14$; S. D. Code (1939) $\$ \S 35.0216-35.0218$; TEns. Code Ann. (Williams, 1934) $\S \S 8113-8118$ (section 8114 was amended, Tenn. Pub. Acts 1941, c. 63, so as to provide for ancillary probate either in common or in solemn form; section 8118 expressly provides for contesting validity of will as to realty in same manner as upon original probate); Utah Code ANn. (1943) $\$ \$ 102.3 .22-102.3 .24$; VT. Pub. LAws (1933) $\$ \$ 2768$ 2770 ; WIs. STat. (1941) $\$ 310.07$ (restricted to foreign record of probate at the domicile); Wyo. Rev. Stat. AnN. (Courtright, 1931) $\$ \$ 88.301-88.304$.

83. 9 U. L. A. (1942) 755. It is particularly regrettable that the Uniform Act contains the deficiencies about to be discussed in the text. Wide adoption of a good uniform act relating to ancillary probate, providing expressly for recognition of the domiciliary decree as conclusive on essential validity of the will, would seem to be the most effective way to prevent wills contests in each of the several states where property is situated. 
sidered open when a will is offered for ancillary probate. It is, of course, perfectly consistent with a true ancillary probate to permit notice to interested parties and a hearing before admittance, but the issues should be confined to authenticity and proper authentication of the foreign record, whether the foreign decree is still in full force and effect, whether there is local property upon which the will may operate, and other related matters not inconsistent with recognition of the foreign domiciliary decree as conclusively establishing essential validity of the will until it is vacated or nullified in a proper proceeding in the state where entered. Another critical obserration may be made concerning those statutes which provide for the "same force and effect" as an original probate. All of them, save those in Wisconsin ${ }^{84}$ and Delaware, ${ }^{85}$ accept without discrimination authenticated probates from any other state without regard to the domicile of the decedent; and many of them accept in like fashion probates from foreign countries. This is another indication that the objective of the legislation is to provide an alternative method of proving the will and that it is not directed to the problem of securing a single final domiciliary probate where property is in several states. There is no objection, of course, to this method of proof where a non-domiciliary foreign decree is involved, but the statutes might well discriminate between the foreign decrees as to their conclusiveness in the local proceeding. In view of the above discussion of these statutes, it seems needless to cite and discuss cases which hold they do not require that a conclusive effect be given foreign decrees. Before leaving them, however, it should be observed that in a number of cases the courts have, in fact, placed some reliance upon them in holding or stating that the foreign decree is conclusive after local ancillary probate. ${ }^{88}$

Another group of statutes relating to ancillary probate upon authenticated record of foreign probate expressly provides for contest in the same manner as wills offered for original probate in the state, ${ }^{87}$ or within a

84. Wis. Stat. (1941) $\$ 310.07$.

85. DeL. Rev. CODE (1935) $\$ 3711$.

86. MIurdoch v. Mfurdoch, S1 Conn. 6S1, 72 Atl. 290 (1909); Harris v. Harris, 61 Ind. 117 (1878) ; cf. Evansville Ice \& Cold Storage Co. v. Winsor, 148 Ind. 6S2, $48 \mathrm{~N}$. E. 592 (1897) ; Kurtz v. Kurtz's Estate, 169 .fd. 554, 182 Atl. 456 (1936) ; Baheocls v. Cullins, 60 Minn. 73, 61 N. W. 1020 (1895) ; State e.r rel. Ruef v. District Court, 34 Mont. 96, 85 Pac. $\$ 66$ (1906) ; Ives v. Heirs of Salisbury, 56 V't. 365 (1883) ; $d$. Walton v. Hall's Estate, 66 Vt. 455, 29 Atl. 803 (1894) ; Simpson v. Cornish, 196 Wis. 125, 218 N. W. 193 (1928); In re Gailey's Will, 169 Wis. 444, 171 N. W. 945 (1919).

87. Alaska Coarp. Laws (1933) $\$ \S 4626-27$; ARk. Dig. Srat. (Pope, 1937) $\S \S 14534$, 14557-59; Fla. Stat. AxN. (1941) \$§ 732.30, 732.35, 732.38; GA. Code (1938) §113.702 (as to real estate, but see section 113.703, providing that if probated in state of testator's residence, ancillary probate "may be attacked or resisted on the same grounds as other judicial proceedings from a state of the United States") : Irl. Rev. Srar. (Bar Ass'n Ed, 1943) c. 3, \$242; Iowa Code (Reichmann, 1939) \$\$11878, 11882; AIrss. Code Awm. 
specified time after admission. ${ }^{88}$ This is the only group of statutes which clearly and unequivocally precludes the possibility of regarding a foreign domiciliary probate as conclusive on essential validity of a will when admitted to ancillary probate. Yet, despite a statute of this kind, the Supreme Court of Texas has declared that such conclusive effect is required by the full faith and credit clause of the Federal Constitution. ${ }^{80}$ The Court of Civil Appeals relied upon the statutes in holding that the foreign will was subject to contest in Texas on the ground of forgery; but the Texas Stpreme Court virtually ignored the statutes in holding that no contest was open. If the Supreme Court's premise was correct, it rightly ignored the statutes as unconstitutional; but, as has been observed, the United States Supreme Court has not enforced upon the states the maxim mobilia sequuntur personam as a principle of constitutional law in these matters.

The Minnesota statute does not fit readily into any of the above classifications. It provides for hearing and for notice as in original probate, and then continues: "If such will was admitted to probate by a court of competent jurisdiction and if the order, judgment, or decree of admission to probate is still in force, the court shall allow the will and appoint a representative as if the will were originally proved and allowed in such court."100 When taken in connection with another provision of the code, ${ }^{91}$ which precludes contest on the validity of wills unless objections are filed at or before hearing for admission, this statute is the clearest legislative directivt which has been found that the foreign probate shall be conclusive. The inference seems plain that the only issues open upon the hearing for ancillary admission are the validity of the foreign decree and whether it is still in force. This inference is strengthened by the fact that prior to the adoption of the statute in its present form, the Minnesota Supreme Court had said a foreign domiciliary decree was conclusive "and the proceedings by which it ... [was] probated in this state . . mostly a matter of

(1930) § 1614; Mo. Rev. Stat. (1939) §554; Ore. Conrp. Laws ANN. (1940) $§ 18.703$; TEnn. Code Ans. (Williams, 1934) $\$ 8118$ (may be contested as to realty); TEx. ANN. Rev. Civ. Stat. (Vernon, 1941) art. 3352, 8301.

88. Ariz. Code Ann. (1939) §38.216; W. VA. Code ANn. (Michic, Sublett \& Steclman, 1943) $\S 4073$. The West Virginia statute provides that "any person interested, may, within two years from the time such authenticated copy is admitted to record, upon rensonable notice to the parties interested, have the order admitting the same set aside, upon due and satisfactory proof that such authenticated copy was not a true copy of such will, or that the probate of such will has been set aside by the court by which it was admitted to probate, or that such probate was improperly made." This statute seems susceptible to a construction precluding contest on essential validity of the will.

89. Holland v. Jackson, 121 Tex. 1, 37 S. W. (2d) 726 (1931). Another decision reaching the same result as to personal property, on the same grounds, is Martin v. Stovall, 103 Tenn. 1, 52 S. W. 296 (1899). The dissenting opinion of Wilkes J., id. at 15, was on more solid grounds.

90. Minn. Stats. 1941, §525.271.

91. Minn. Stats. 1941, § 525.241. 
form." 92 The statute at that time provided that the will should have the same force and effect as if it had been originally proved and allowed in the same court. For purposes of this investigation, however, the present Minnesota statute retains one serious defect. It does not discriminate between a domiciliary and a non-domiciliary decree as to the issues open in opposition to local admittance.

\section{Conclusion and Suggestions for Statutory Changes}

When a decedent leaves property in several states, the lawyer charged with the task of getting it properly administered is confronted with problems in the conflict of laws. In a typical case, in accordance with the traditions of our law, he opens an administration in the state of the decedent's last domicile. Because of the wide application of the maxim mobilia sequnntur personam in decedents' estate matters, he is justified in regarding that administration as the primary one. If an administration proceeding proves to be necessary in another state, however, he must face the possibility that in many important matters the ancillary court will go its own way. This study has been concerned with the question whether, in case there is a will, the domiciliary probate decree may be relied upon as conclusively establishing the status of testacy or of intestacy for the entire estate. The answer is that in some states it may be so relied upon and in other states it may not; in some states it may be relied upon as to personal property, but not as to real property; in still other states the problem remains in doubt and uncertainty. This conflict and uncertainty is accompanied by, and to a large extent caused by, confusion in terminology and understanding of basic principles.

The greatest source of confusion is to be found in loose use of the term "jurisdiction." It may mean a number of different things. ${ }^{03}$ It seems to the writer that basically it should mean the power of a court under its own law and procedure to hear and determine a controversy in such a way as to be conclusive within the state, subject only to reversal by a reviewing court. This conception should include any restrictions which may be enforced upon it by the United States Supreme Court under the due process clause or other provisions of the Constitution since, after all, the Constitution is the supreme law of all the states. It has become customary, however, to speak of "jurisdiction" as the power to decide a controversy in such a way that courts in other states and nations will "generally" regard the judgment as conclusive. ${ }^{9 t}$ This usage confuses two distinct conflict of laws problems, which may profitably be kept distinct. The extraterritorial effect of a valid judgment should not be considered a problem

92. Babcock v. Collins, 60 Minn. 73, 77, 61 N. W. 1020, 1021 (1895).

93. See 2 PAGE, op. cit. supra note $2, \S 572$.

94. See note 6 supra. 
of "jurisdiction," and it should be differentiated from the question of validity of a judgment in the state of rendition, whether validity is questioned within or without the state.

This failure to differentiate the problems of jurisdiction and the extraterritorial effect of probate decrees has resulted in much confusion in application of the full faith and credit clause of the Federal Constitution to the probate field. This confusion is frequently worse confounded by failure to differentiate the additional related problem of choice of law. The courts in some states, confronted with ancillary administration of the property of a nonresident decedent, have extended the application of the maxim mobilia sequintur personam from the choice of law problem to the matter of recognition of the domiciliary probate decree. They seem to feel that such recognition must necessarily follow from the choice of law rule. Since the common law choice of law rule referred the question of validity of a will to the rules prevailing at the decedent's domicile as to personal property and to the law of the situs as to real property, it was thought to follow that a domiciliary decree was conclusive as to personal property, but inconclusive as to real property. When the common law choice of law rule is changed by statute so as to permit an alternative reference to the law of the domicile, the rule as to recognition is sometimes changed accordingly even as to real estate. The next step in the reasoning is to say that since the foreign court had "jurisdiction" its decree must be respected under the full faith and credit clause. This conclusion is spurious as applied to a foreign decree operating in rem. It is spurious because the United States Supreme Court has not required that such a decree be respected as to property in another state, and it is not likely to do so. Where, however, the foreign decree also operates in personam, it is highly probable that it must be respected elsewhere as to all persons who were parties in F-1 or so represented there as to be bound in personam.

Other courts, confronted with the same problem, have approached it from the premise of physical power. It is said that no court has "jurisdiction" over property not within the state. The foreign probate decree, operating in rem, can have no effect upon local property; and in the absence of "jurisdiction" the matters determined therein are not entitled to full faith and credit. It is said to follow that despite the foreign decree, a contest is open when the will is offered for ancillary probate. While it may be quite true that full faith and credit as to local property is not required by the Federal Constitution, the conclusion that a local contest is open does not necessarily follow. Whether it is open depends upon the common law or statutory conflict of laws rule in F-2 concerning the effect to be given the foreign judgment, which, in turn, depends upon the policy of F-2 with respect to the proper function of ancillary administration. If F-2 
decides to go its own way in the matter, there is little that can be done about it except to change the rule by legislation. If it decides to preclude litigation upon some or all of the matters determined in F-1, it not only gives some real meaning to the term "ancillary administration" in estates matters, but it contributes a great deal to a unified administration of the entire estate when F-1 is the domiciliary court.

Existing legislation on ancillary probate in some states expressly precludes a conclusive effect to the primary decree. In most of the states the legislation is indefinite and does not adequately meet the problem. The Uniform Wills Act, Foreign Probated, falls in the latter category. The Commissioners on Uniform State Laws now have under consideration tentative drafts for two additional acts relating to powers of foreign representatives and ancillary administration of estates. ${ }^{95}$ These drafts do not purport to codify all of the principles of conflict of laws relating to interstate administration. The objective is to obviate unnecessary ancillary administration and to facilitate a unified administration in cases where ancillary administration is desirable. Section 9 of the draft on ancillary administration deals with the effect of judgments in another jurisdiction, but it contains no provision concerning the local effect of the foreign domiciliary probate decree. ${ }^{96}$ It is directed solely to the problem of privity between representatives of the same estate appointed in different states as to judgments obtained by or against them in the course of administration. The exclusion from this draft of any provision concerning the effect to be given the domiciliary probate decree is probably due to the existence of the Uniform Wills Act, Foreign Probated, the inadequacy of which has been noted above.

95. Handeook of the National Conference of Commissioners o: Uniforar State Laws (1942) 237 et seq.

96. Section 9 of the 1942 draft provided in part: "Exeept in case of fraud in their procurement, judgments in administration proceedings or in actions by or against any representative in another jurisdiction shall be as conclusive as to the loeal representative or local and foreign representative as if the same were rendered in the administration in this state, or in actions by or against the local representative or local and foreign representative by a court of this state" Handooor of trie N.tTional Co:rerkence of Co:sMISSTONERS ON UNIForas STATE LAws (1942) 262. It seems clear that the reference in this section to "judgments in administration proceedings" was not intended to include a foreign decree of probate. The rest of the sentence, as well as the comment upon the section by its exceptionally able draftsman, indicated that the problem comprehended was the matter of privity between representatives of the same estate appointed in different states as to judgments obtained by or against them in the course of administration. At all events, it is the heir at law and not a representative who is likely to contest ancillary probate of a will, and this section provided a conclusive effect only as to representatives. Any possible ambiguity in the scope of the section has been eliminated from the 1943 drait by exclusion of the reference to "judgments in administration procedings." NATro:isL. Confereatce of Comanissioners on Uniforar State Laws, Report of Spectal CozranttEe on Uniforar Anciliary AdMinistration of Estates ACt (1943) 12. 
Legal reforms usually come slowly and often piecemeal; but despite the opposition which may be expected to the limited objectives of these tentative drafts, it would seem that while the Commissioners are considering improvements in the law of ancillary administration, they might well include the problem of conclusiveness of the domiciliary probate. In a sense, the problem is a crucial one going to the very basis of the proper function of ancillary administration. Perhaps a simple legislative directive on that matter requiring recognition of the domiciliary decree would serve to extricate the courts from their entanglement in conflicting theories of "jurisdiction," and set them on their way toward a more simple and unified administration of an estate extending across state lines.

The precise form of such a model statute precluding wills contests upon ancillary probate would depend upon other related provisions of the probate code. The following suggestions merely relate to a few of the matters a draftsman of ancillary probate legislation should have in mind.

In most states the statutes quite properly permit ancillary probate upon authenticated record of a foreign proceeding without regard for the testator's domicile. This provides a convenient method for proving a will which is in the files of a foreign court and may not be readily available. For reasons heretofore suggested, however, it is believed that only a domiciliary decree should be accepted as conclusively establishing the will. Not only would such discrimination contribute to a unified administration centered at the domicile, but it would prevent effectuation of fraud. It may be assumed that anyone who has procured a will in his favor by undue influence or fraud, or who has forged a will would not hesitate to propound the document in some state where the testator left property and where prospective contestants would be least likely to anticipate production of a will. Production of a will at the domicile, however, may always be anticipated; and it seems appropriate for that reason to make the discrimination and to accept the domicile as the one appropriate jurisdiction for a final determination of validity of the will. In case the decedent's domicile is in dispute, that question would be an issue of fact for determination when probate is requested upon foreign authenticated record. Under present law a decree finding local domicile is not regarded as conclusive in other states on persons not parties to the first proceeding and is not entitled to full faith and credit under the Constitution. ${ }^{97}$ It is usually said that domicile is a "jurisdictional fact" which may be questioned in F-2 under the rule that in F-2 the jurisdiction of F-1 is always open to inquiry. Domicile usually is not a jurisdictional fact, however, in the sense in which "jurisdiction" is used herein. The presence of property in F-1 provides an adequate basis for probate in that state. Whether the finding of domicile is correct or erroneous, it is ordinarily not subject to collateral attack in the

97. For an extensive collection of cases, see Note (1939) 121 A. L. R. 1200. 
state where entered, and as to parties bound by the decree in personam as well as in rem, it is probably not subject to collateral attack elsewhere. But domicile often is, and always should be, a crucial fact in determining what recognition is to be give a foreign decree upon which local administration is founded. No ex partc determination of that fact by a foreign court should be conclusive in F-2 in case of conflicting claims of domicile. In view of the existing law, it should be unnecessary to provide expressly by statute that a foreign decree fixing domicile is not conclusive on that question, although such a provision might be useful in preventing misapplication of a statute providing for recognition of a foreign domiciliary decree.

Under existing practice, both statutory and common law, it usually is permissible to admit a foreign will to original probate in a non-domiciliary state where property subject to the will is situated, although it has not been presented for probate at the domicile. ${ }^{88}$ This practice seems desirable and should not be changed $;^{99}$ but its retention suggests the question whether it should be extended to the case of a will presented for probate at the domicile, rejected there, and then offered for original probate in another state. The answer is clearly that it should not if the domiciliary court is accepted as the appropriate forum for final determination of the status of testacy or intestacy. The ancillary probate statutes, however, are not applicable to this question. If, as has been suggested, the matter of recognition is handled by a provision in the ancillary administration code to the effect that the domiciliary decree upon which ancillary administration is founded be accepted as conclusively establishing the status of testacy, then it would be necessary to draft a companion statute. Such a statute should provide, in effect, that original probate of a foreign will shall not be permissible where it has been rejected at the domicile on grounds of essential invalidity.

98. For an extensive collection of cases, see Note (1939) 119 A. L. R. 491.

99. A contrary rule, requiring that foreign wills be admitted at the domicile as a prerequisite to probate in another state, would force needless domiciliary probate in cases where there is no property at the domicile; and, furthermore, where a will fails because of noncompliance with domiciliary standards of exceution, it wuld consequently fail at the situs as well, although executed in compliance with the standards there. An illustration of the latter difficulty may be found in In re Dodge's Will, $\$ 9$ N. J. Eq. 525, 104 Atl. 646 (1918). The testator died domiciled in Georgia, having previously executed a will in compliance with New Jersey law while domiciled in New Jersey. The will was refused probate in Georgia because not executed with the requisite formalities of Georgia statutes. There was real property in New Jersey upon which the will operated, but the New Jersey court refused to admit the will on the ground that under its statutes there could be no original probate of the will of a testator domiciled outside New Jersey even though the will was sufficient in form to pass New Jersey property. Soon after the decision the rule of New Jersey was changed by statute. See N. J. REv. Star. (1937) tit. 3, c. 2, §41. 
Rejection at the domicile on the grounds of formal invalidity, however, should not preclude original probate elsewhere. Existing choice of law statutes usually permit alternative reference points as to standards of formal validity. One of those reference points should be the law of testator's domicile; and, in that event, a decree admitting the will at the domicile could be conclusive on issues of formal as well as essential validity. But rejection of the will at the domicile for formal invalidity should not preclude probate elsewhere of a will executed in accordance with local standards or the standards of some other reference point permissible under the local choice of law rule. In view of the policy of our law, often expressed in the cases favoring liberty of testation, there would seem to be no justification for abandoning the present choice of law statutes, which permit alternative reference points for rules of formal validity, and requiring execution in accordance with the domiciliary standards. The underlying principles governing the ceremony of wills execution are substantially alike in all the states, but there is great variety in the details. The minor differences often lead to an unfortunate partial intestacy where property is situated in several states. Provision for alternative reference points would seem the best way to meet the situation until such time as the states are able to agree upon a standard ceremony, such as the one found in the Model Execution of Wills Act recently offered by the Commissioners on Uniform State Laws. ${ }^{100}$

Where a will has been denied probate at the domicile on the ground that it has been revoked, the courts in other states are confronted with other problems in proper correlation of choice of law rules and the effect to be given to the domiciliary decree. The common law choice of law rules referred the matter of revocation to the law of the domicile as to personal property and to the law of the situs as to real property. Concerning revocation by subsequent act of the testator, the common law rules have been found too restrictive in a number of states; and the statutes provide the same alternative reference points for a valid revocation as are provided for standards of formal validity. These statutes are applicable to both real and personal property. ${ }^{101}$ What has been said above in regard to correlation between choice of law on standards of formal validity and the effect of the domiciliary decree would seem to be equally applicable here. A policy of liberty of testation should include the liberty of intestacy, and the testator's purpose in that regard should not be defeated by minor technical differences in formal standards of revocation in the several states. A draftsman with a broad mandate to reform the law of ancillary administration might well consider the advisability of providing alternative ref-

100. 9 U. L. A. (1942) 277.

101. Mont. Rev. Codes Ann. (Anderson \& McFariand, 1935) $\$ 6988 ;$ N. D. Comp. Laws Ann. (1913) §5653; Okla. Stat. Ans. (1938) tit. 84 , $\$ \$ 71-72$; S. D. Code (1939) §56.0212; UTAH CODE ANN. (1943) §101.1.14. 
erence points for standards of revocation and providing as one of the permissible reference points the law of the testator's last domicile. If that is done, a will denied probate at the domicile because revoked under the domiciliary law would not be entitled to probate in another state, and the domiciliary decree rejecting the will would be conclusive on that issue. A domiciliary decree, howerer, which admits a will after finding an attempted revocation ineffective, would not preclude a showing in the ancillary administration that the will had been revoked as to local property in accordance with provisions of the local law.

Where the problem is revocation by operation of law rather than by subsequent act of the testator, the considerations of policy involved are quite different. Liberty of testation is obstructed, not by minor formal differences in standards of execution and revocation, but by limitations designed to protect dependents from thoughtless or intentional exclusions on the part of the testator. As usual, the common law rules referred this problem to the law of the testator's domicile as to personal property and to the law of the situs as to real property. ${ }^{102}$ There seems to be little disposition to change these rules either by statute or decision. So long as they are followed, a domiciliary decree should be entitled to recognition as to personal property and not as to real property on the issue of revocation by operation of law. ${ }^{103}$ A draftsman of legislative reform, however, might have to weigh the local policy concerning revocation by operation of law against the policy of giving a conclusive effect to a foreign domiciliary decree on that issue. He would find available at least one precedent for change. The Wisconsin Supreme Court extended the implications of its ancillary probate statute beyond its express requirements and gave the foreign domiciliary decree a conclusive effect as to existence and validity of a will. It held that a will of Wisconsin land which was denied probate at the domicile because revoked by subsequent marriage of the testator, was not entitled to probate in Wisconsin, even though marriage without issue was not a revocation under Wisconsin law. ${ }^{104}$

It should not be inferred from the somewhat detailed suggestions submitted above that a complete statutory system of ancillary probate is ad-

102. In re Smith's Estate, 55 Wyo. 181, 97 P. (2d) 677 (1940) (indicating that one source of conflict of laws problems is the difference in rule among the states as to whether a woman's will is still, as at common law, revoked by marriage alone without the birth of issue).

103. Evansville Ice \& Cold Storage Co. v. Winsor, 148 Ind. 682, 48 N. E. 592 (1897); Barnes v. Graves, 259 Ky. 180, 82 S. W. (2d) 297 (1935); Sueed v. Eving, 5 J. J. Mar. 460 (Ky. 1831); Cohen v. Herbert, 205 11o. 537, 104 S. W. S4 (1907); Cornell v. Burr, 32 S. D. 1, 141 N. W. 1081 (1913); cf. Crossett Lumber Co. v. Files, 104 Ark. 600, 149 S. W. 908 (1912).

104. In re Gailey's Will, 169 Wis. 444, 171 N. W. 945 (1919); of. In re Hebblewhite's Will, 228 Wis. 259,280 N. W. 384 (1938) (construction of foreign will). 
vocated. Perhaps no draftsman could anticipate and provide a complete solution for all of the complex problems of choice of law and recognition of foreign judgments and the correlations between the two which might arise in interstate administration. These suggestions are intended to aid in placing those problems into proper focus with reference to the underlying problem of "jurisdiction," which has been the source of most of the confusion in the past. A simple legislative directive to the effect that in ancillary administration the domiciliary decree shall be given a conclusive effect as to existence and validity of a will might be adequate to set the courts upon a course of true ancillary administration. The great constructive traditions of the common law might then be relied upon for reexamination and possible modification of common law choice of law rules. 